\title{
An Agent-Based Model to assess COVID-19 spread and health systems burden in Telangana state, India
}

\author{
Narassima M S ${ }^{\mathrm{a}}$, Guru Rajesh Jammy ${ }^{\mathrm{b}}$, Sankarshana A ${ }^{\mathrm{c}}$, Rashmi Pant ${ }^{\mathrm{b}}$, Anbuudayasankar S P ${ }^{\mathrm{a}^{*}}$, Lincoln \\ Choudhury ${ }^{\mathrm{d}}$, Vijay Yeldandi ${ }^{\mathrm{b}}$, Shubham Singh ${ }^{\mathrm{e}}$, Denny John ${ }^{6}$ \\ ${ }^{a}$ Department of Mechanical Engineering, Amrita School of Engineering, Coimbatore, Amrita Vishwa Vidyapeetham, \\ India. \\ ${ }^{b}$ Society for Health, Allied Research and Education (SHARE-INDIA), Telangana, India. \\ ${ }^{c}$ Department of Computer Science Engineering, Amrita School of Engineering, Coimbatore, Amrita Vishwa \\ Vidyapeetham, India. \\ ${ }^{d}$ Krashapana Consultancy Private limited, New Delhi, India. \\ ${ }^{e}$ Assistant System Engineer, Tata Consultancy Services Limited. \\ ${ }^{f}$ Amrita Institute of Medical Sciences and Research Centre, Amrita Vishwa Vidyapeetham, Kochi, Kerala, India
}

\begin{abstract}
Objectives: To assess the transmission dynamics and the health systems' burden of COVID-19 using an Agent Based Modeling $(\mathrm{ABM})$ approach using a synthetic population.

Study design: The study used a synthetic population with 31,738,240 agents representing 90.67 percent of the overall population of Telangana state, India as per 2011 Census of India. Lockdown phases as per Indian scenario considering the effects of postlockdown, use of control measures and immunity on secondary infections were studied.

Methods: The counts of people in different health states were measured separately for each district of Telangana. The model was run for 365 days and six scenarios with varying proportions of people using control measures $(100 \%, 75 \%$ and $50 \%)$ and varying immunity periods (90 and 180 days). Sensitivity Analysis has been done for two districts to compare the change in transmission dynamics when incubation period and asymptomatic proportion are changed.
\end{abstract}

Results: Results indicate that the peak values were attained soon after the lockdown was lifted. The risk estimates indicate that protection factor values are higher when more proportion of people adopt control measures.

Conclusions: ABM approach helps to analyze grassroot details compared to compartmental models. Risk estimates allow the policymakers to determine the protection offered, its strength and percentage of population shielded by use of control measures.

Key words

Agent Based Model; COVID-19; SARS-CoV-2; Coronavirus; India

\section{Introduction}

On Jan 30, 2020, India reported its first infection of Covid-19 (SARS-CoV-2) during when WHO categorized Covid-19 to be "Public Health Emergency of International Concern" (PHEIC), owing to the serious impacts that could be caused by the infection [16;53]. The world has witnessed an enormous outbreak of the epidemic with $34,503,272$ infections and 1,027,138 deaths across 213 nations worldwide, as on September 30, 2020 resulting in a global health crisis [77]. In India, total infections reported are 6,310,267 with 940,643 active cases, 5,270,007 recoveries and 98,708 deaths, till September 302020 [17]. Countries like India, with higher population densities have a greater concern owing to the influx of infections [38]. The severity of infection and recovery varies from case to case, majorly governed by some parameters such as comorbidities, age, exposure to virus particles, air pollution, 
etc. [19; 44]. In addition, majority of the infections being asymptomatic raise a serious threat as they remain untraceable and continue to transmit the infection $[19 ; 44 ; 72]$. There is a lot of work being done by researchers, policymakers, healthcare professionals across various disciplines to rapidly eradicate the spread of the infection [26; 52].

Several studies on infectious diseases dealing with containment of diseases such as tuberculosis [55], measles [23], etc., operationalizing antiviral prophylaxis to control H5N1 influenza and distancing [25], strategizing evacuations in the case of airborne infections [24], establishing vaccination techniques for smallpox [34], influenza [15], etc. Presently, ABMs have been developed to study COVID-19 related scenarios like the effectiveness of imposing lockdowns [40; 51; 68; 71], post-lockdown control strategies [37], insulation of vulnerable population [37; 36], direct and indirect transmission (via viral particles in air) [40], effect of control measures like distancing and face mask [37; 43], transmission based on viral-load [43], population intelligence [68], contact tracing initiatives [43; 68], contacts based on schedule and locations [21; 37; 40], etc.

Most studies from India on COVID-19 have largely followed compartmental approach adhering to either the basic Susceptible (S), Infective (I) and Recovered (R) model or its variations that include additional states. These include, the Susceptible (S), Exposed (E), Symptomatic (I), Purely Asymptomatic (P), Hospitalized or Quarantined (H), Recovered (R) and Deceased (D) (SIPHERD) [50], Susceptible (S), Exposed (E), Infective (I) and Recovered (R) (SEIR) [13; 66; 74; 78], analytical models [2; 67].

Simulation models map the real-world behaviour through a set of rules, with the defined level accuracy, subject to constraints [6;7]. These models eliminate the investment of cost, time and associated risks [7; 48]. Complex problems involving dynamicity are much effectively handled by simulations [30]. Three widely used simulation approaches are System Dynamics (SD), Discrete Event Simulation (DES) and Agent Based Modeling (ABM). SD and DES provide only collective measures whereas ABM holds granular details of individual agents [11; 69]. ABM allows modelers to define parameters uniquely to agents $[12 ; 30 ; 69]$.

ABMs are resultant of advancements in science and technology and the ability of systems to handle complexities [30; 49]. In recent times, these models are sought by researchers across various sectors [33; 31; 32]. ABM incorporates a bottom-up approach wherein the behavior of agents cumulate to the behaviour of the system [12; 27]. This has attracted the public health researchers and practitioners as they can observe the actions of individuals and clearly apprehend the population dynamics better $[6 ; 60]$. However, the computational capabilities majorly govern the potential of ABMs [49]. In this paper, we have used ABM approach to analyse outbreak and health systems burden on COVID-19 in Telangana state. Multiple NPIs have been considered simultaneously as enforced by the Swiss Cheese model so that each layer curtails the spread of infection to some extent [29; 56]. This has been in use by hospitals to establish multiple defense strategies [56] and also by policymakers to impose multiple interventions [29].

\section{Methodology}

\subsection{Research design}

The current study employs an Agent Based Modeling (ABM) approach to analyze the outbreak and health systems burden for Covid-19 with the synthetic population of Telangana state (Table 1). The model was coded in python using PyCharm (Version: 2020.1.3). Python being an Object-Oriented Programming (OOP) language was chosen to code the model as OOP are more suitable for ABM [4]. The model was run for 365 days considering the lockdown phases as per Indian scenario (Table 3). The study involves agent creation, establishing a contact network, creating a disease model and initializing the model. This is followed by running the model, extracting and analyzing the results and providing useful interpretations. Public health policies and recommendations are underpinned based on the estimations of the mathematical models devised [9; 63]. The code, scenarios, parameters and scope of the model are all made transparent in the present study and adheres to ethical good practices in modelling and International Society for Pharmacoeconomics and Outcomes Research (ISPOR-SMDM) Modeling Good Research Practices $[9 ; 10 ; 63]$.

\subsection{Agent creation}

Synthetic population developed using the 2011 Census of India data for 31,738,270 people was used to generate agents. Agent attributes such as person ID, age, household ID, geocoordinates, and district code were assigned to each agent. During this process, 30 invalid records were skipped thereby making the valid number of agents to be 
medRxiv preprint doi: https://doi.org/10.1101/2020.10.03.20206177; this version posted October 19, 2020. The copyright holder for this preprint (which was not certified by peer review) is the author/funder, who has granted medRxiv a license to display the preprint in perpetuity.

It is made available under a CC-BY-NC-ND 4.0 International license .

$31,738,240$ (Table 1). This count represents 90.67 percent $(n=35,003,674)$ of the overall Telangana population as per 2011 Census $[57 ; 70]$.

\subsection{Contact network}

Transmission of an infection is majorly governed by transmission rates and contact network. As per the WHO report on COVID-19 (16 to 24 Feb 2020), transmission rates were randomly varied from 3 to 10 percent for household and closer contacts and 1 to 5 percent for other contacts [5]. To establish varying contact rates for each district, a Density-Dependent contact rate was assumed [39; 58]. Kumar et al. (2018) determined the contact rates for close contact infections by considering the case of Ballabgarh, India [47]. The population density of Ballabgarh and those of the ten districts of Telangana chosen for the study were used to derive the contact rates for the ten districts. The ratio of the population density of Ballabgarh to that of each district would be the corresponding multiplication factor to scale up the number of contacts made by each person in Ballabgarh, as presented by Kumar et al. (2018) [39; 47; 58]. The distributions followed by the datasets consisting the contact rates of individuals of each district were determined using Arena's 'Input Analyzer' tool (Arena 16.00.00002) (Table 1). The tool generates different distributions to which the input datasets could fit, with the associated errors [65].

Table 1: Number and contact rate distributions of agents

\begin{tabular}{|c|c|c|c|c|c|c|c|}
\hline \multirow{2}{*}{$\begin{array}{l}\text { District } \\
\text { Code }\end{array}$} & \multirow{2}{*}{ Name } & \multicolumn{2}{|c|}{ Number of agents } & \multirow{2}{*}{$\begin{array}{l}\text { Number of } \\
\text { households }\end{array}$} & \multicolumn{3}{|c|}{ Distribution of contact rate (per day) } \\
\hline & & Valid & Invalid & & Less than 5 & 5 to 59 & 60 and above \\
\hline 28532 & Adilabad & 1485539 & 5 & 348733 & Gamma $(3.36,1.1)$ & Gamma $(4.86,1.1)$ & Gamma $(5.11,0.78)$ \\
\hline 28533 & Nizamabad & 2305194 & 1 & 538087 & Gamma $(3.53,2.27)$ & Gamma $(4.86,2.35)$ & Gamma $(5.11,1.67)$ \\
\hline 28534 & Karimnagar & 3670101 & 3 & 947624 & Gamma $(3.13,3.18)$ & Gamma $(4.86,3.03)$ & Gamma $(5.11,2.16)$ \\
\hline 28535 & Medak & 2730312 & 4 & 612530 & Gamma $(4.32,1.51)$ & Gamma $(4.86,1.76)$ & Gamma $(5.11,1.26)$ \\
\hline 28536 & Hyderabad & 6855177 & 3 & 1566574 & Gamma $(2.54,144)$ & Gamma $(4.14,129)$ & Beta $(3.3,7.62)$ \\
\hline 28537 & Rangareddy & 548317 & 6 & 125771 & Gamma $(3.21,3.21)$ & Gamma $(4.86,3.12)$ & $\operatorname{Gamma}(5.11,2.22)$ \\
\hline 28538 & Mahabubnagar & 3629330 & 4 & 786355 & Gamma $(2.67,2.14)$ & Gamma $(4.86,1.8)$ & $\operatorname{Beta}(4.77,10.5)$ \\
\hline 28539 & Nalgonda & 4122388 & 3 & 1030984 & Gamma $(3.99,1.31)$ & Gamma $(4.86,1.46)$ & Beta $(4.92,10.8)$ \\
\hline 28540 & Warangal & 3685156 & 1 & 925262 & Gamma $(3.27,2.16)$ & Gamma $(4.86,2.12)$ & Beta $(5.42,12.1)$ \\
\hline 28541 & Khammam & 2706726 & 0 & 879810 & Gamma $(3.19,2.14)$ & Gamma $(4.86,2.06)$ & Beta $(4.75,10.4)$ \\
\hline Total & & 31738240 & 30 & 7761730 & & & \\
\hline
\end{tabular}

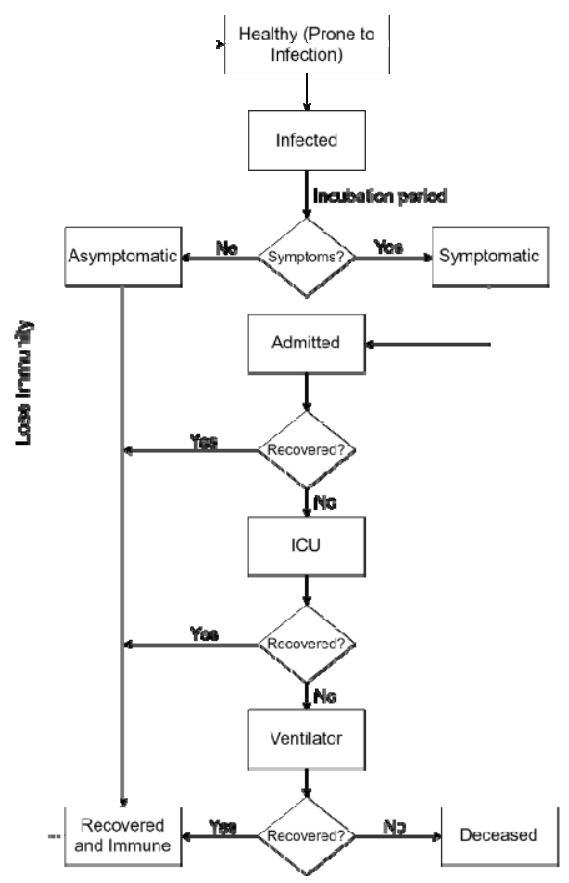


Figure 1: State Chart

\subsection{Disease model}

Disease model helps to represent the agent behaviour and trajectory of a disease using various health states [1]. Each agent can exist in any one of the states described by the state chart at a moment (figure 1). The transition between these states and the duration for which an agent remains in a state are defined as presented in table 2. During the simulation, agents interact based on the contact rates during which an infected agent transmits the infection to a healthy agent. Infected agents who are asymptomatic recover without treatment but continue to transmit the infection till they recover. Symptomatic individuals seek treatment after incubation period. They either recover or decease whilst in any of the treatment levels defined as admitted, ICU and ventilator.

\subsection{Model initialization}

Parameters that are required to drive the model were acquired from various sources including Models of Infectious Disease Agent $\quad$ Study

Table 2: Model parameters

\begin{tabular}{|c|c|c|c|}
\hline Parameters & $5-59$ & $>59$ & References \\
\hline Number of contacts per day & Table 1 & & {$[8 ; 46]$} \\
\hline Probability of getting infected through contact & $\begin{array}{l}\text { i) household/ closer circle: ( } 3 \text { to } 10) \text { percent } \\
\text { ii) other contacts: ( } 1 \text { to } 5 \text { ) percent }\end{array}$ & & {$[5]$} \\
\hline Proportion of people remaining asymptomatic & 0.8 & & {$[22 ; 75]$} \\
\hline Average incubation period (in days) & 5 & & {$[12 ; 79]$} \\
\hline Average treatment duration (in days) & 14 & & {$[79]$} \\
\hline Proportion of hospitalized cases in ICU & 0.11 & & {$[3 ; 28]$} \\
\hline Treatment duration in ICU (in days) & Triangular( $(7,8,9)$ & & {$[28 ; 79]$} \\
\hline $\begin{array}{l}\text { Proportion of people moving from ICU to critical illness } \\
\text { (Ventilator assistance) }\end{array}$ & 0.88 & & [28] \\
\hline Treatment duration in ventilator state (in days) & Triangular $(5,7,12)$ & & [79] \\
\hline Time between symptom arrival and admission (in days) & 3 & & [76] \\
\hline Proportion of people who die & As per Indian statistics & & [17] \\
\hline Risk difference for use of control measures (percentage) & $\begin{array}{l}\text { i) Mask: } 10.2 \\
\text { ii) Distancing: } 14.3\end{array}$ & & [14] \\
\hline
\end{tabular}

\subsection{Model simulation}

The model coded in Python was equipped with the input parameters and run for six different scenarios (table 4) [18]. The lockdown stringency was varied for various phases of lockdowns imposed. The proportion of contacts made by Indians based on locations were determined [61]. To bring in the effect of lockdown, contacts made by people at work and other places were reduced proportionately based on lockdown stringency, the contacts in home were maintained same and the school contacts were nullified.

Table 3: Lockdown phases

\begin{tabular}{|c|c|c|c|c|c|}
\hline Lockdown & Duration & Days & $\begin{array}{l}\begin{array}{l}\text { Lockdown } \\
(\%)\end{array} \\
\end{array}$ & $\begin{array}{l}\text { Contact rate } \\
(\%)\end{array}$ & $\begin{array}{l}\text { Closest contacts } \\
(\%)\end{array}$ \\
\hline Phase 1 & 25 March 2020 - 14 April 2020 & 21 & \multirow{4}{*}{75} & \multirow{4}{*}{42.794} & \multirow{4}{*}{90.749} \\
\hline Phase 2 & 15 April 2020 - 3 May 2020 & 19 & & & \\
\hline Phase 3 & 4 May 2020 - 17 May 2020 & 14 & & & \\
\hline Phase 4 & 18 May 2020 - 31 May 2020 & 14 & & & \\
\hline Unlock 1.0 & 1 June 2020 - 30 June 2020 & 30 & \multirow{2}{*}{50} & \multirow{2}{*}{56.436} & \multirow{2}{*}{81.498} \\
\hline Unlock 2.0 & 1 July $2020-31$ July 2020 & 31 & & & \\
\hline Unlock 3.0 & 1 August $2020-31$ August 2020 & 13 & 25 & 70.077 & 72.247 \\
\hline
\end{tabular}


medRxiv preprint doi: https://doi.org/10.1101/2020.10.03.20206177; this version posted October 19, 2020. The copyright holder for this preprint (which was not certified by peer review) is the author/funder, who has granted medRxiv a license to display the preprint in perpetuity.

It is made available under a CC-BY-NC-ND 4.0 International license .

\begin{tabular}{llllll}
\hline Post Unlock & After 31 August 2020 & NA & 0 & 100.000 & 62.995 \\
\hline
\end{tabular}

\section{Results of Simulation}

The model was run for six different scenarios considering the various phases of lockdown imposed in India, control measures such as use of face mask and social distancing and the impact of immunity on the transmission of infection. The six scenarios would be referred to as MD100I90, MD75I90, MD50I90, MD100I180, MD75I180 and MD50I180 in subsequent sections. The number following 'MD' indicates the percentage of people following control measures and the number following 'I' indicates the days for which people remain immune after recovery. The graphs plotted represent the number of people in each health state for the entire state of Telangana. District-wise counts are provided in the supplementary excel.

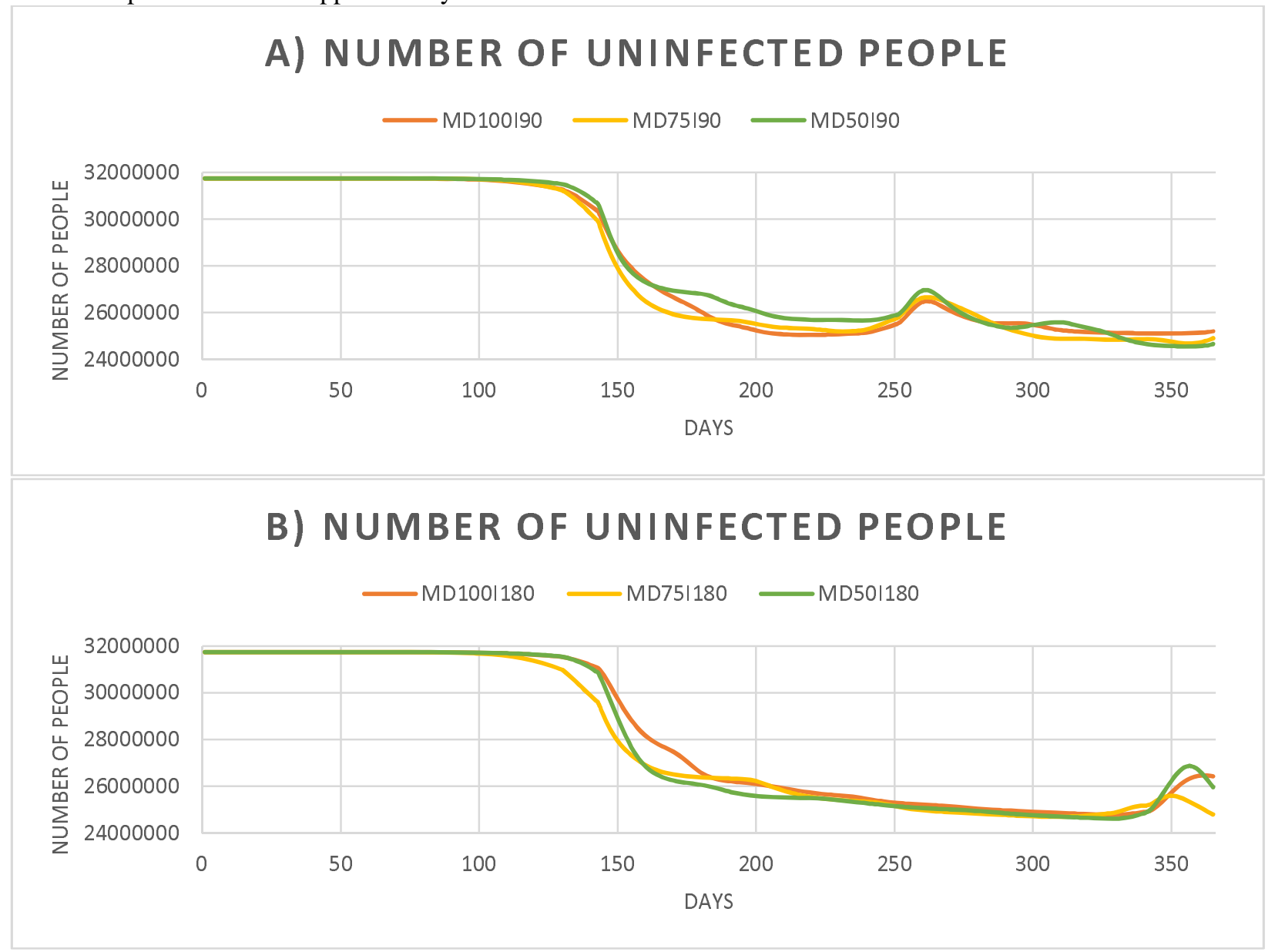

Figure 2 a): Number of Uninfected people (90 days immunity scenarios); b) Number of Uninfected people (180 days immunity scenarios)

It is clear from figures $2 a$ ) and b) that the number of uninfected people decrease significantly once the lockdown has been completely lifted after 142 days. As the stringency of lockdown is reduced, people meet more people increasing the vulnerability of acquiring or transmitting infection. In both these figures, there is a visible increase in the number of uninfected people which indicates the transit of people from immune state to uninfected state i.e., loss of immunity/ prone to infection [62]. 
medRxiv preprint doi: https://doi.org/10.1101/2020.10.03.20206177; this version posted October 19, 2020. The copyright holder for this preprint (which was not certified by peer review) is the author/funder, who has granted medRxiv a license to display the preprint in perpetuity.

It is made available under a CC-BY-NC-ND 4.0 International license.

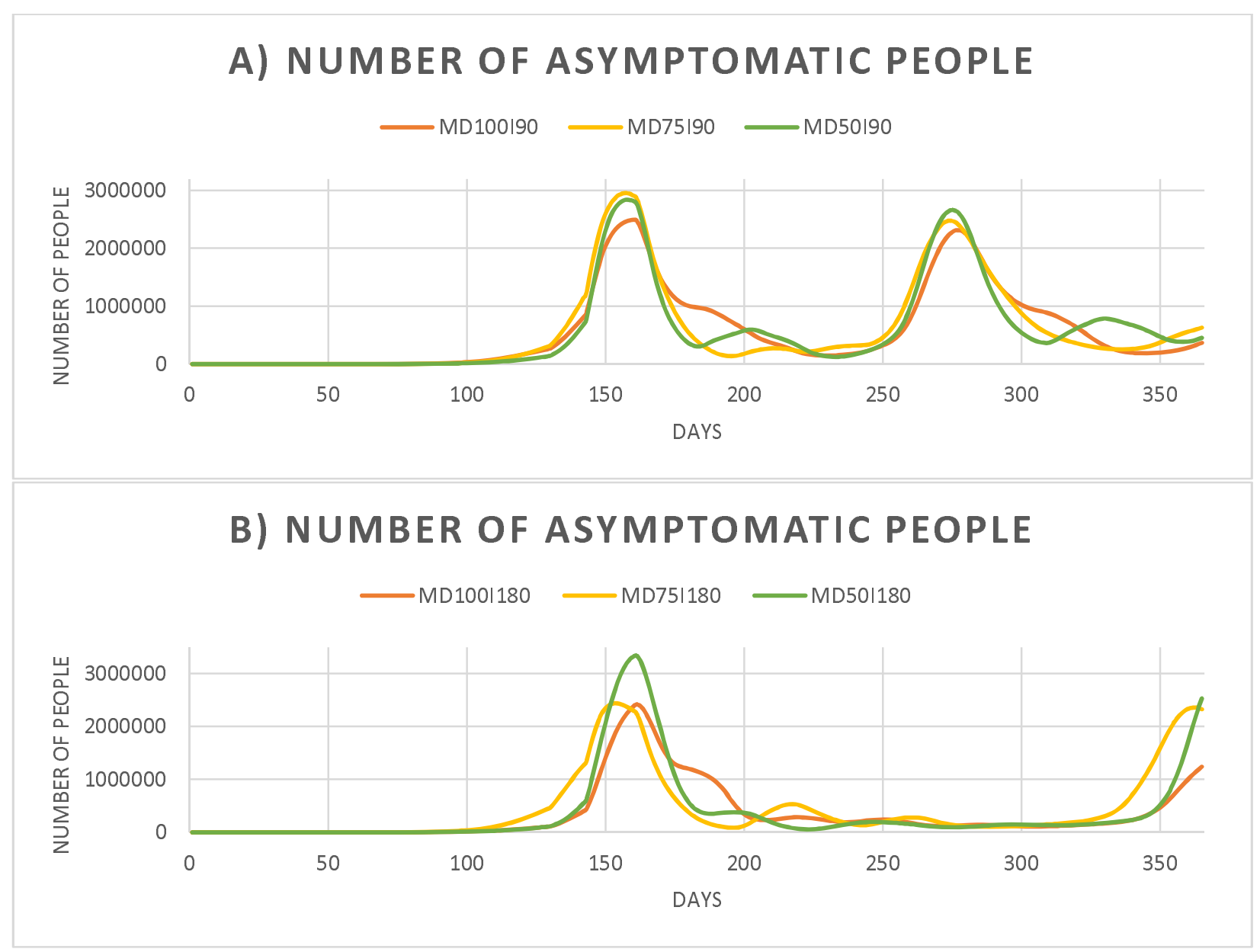




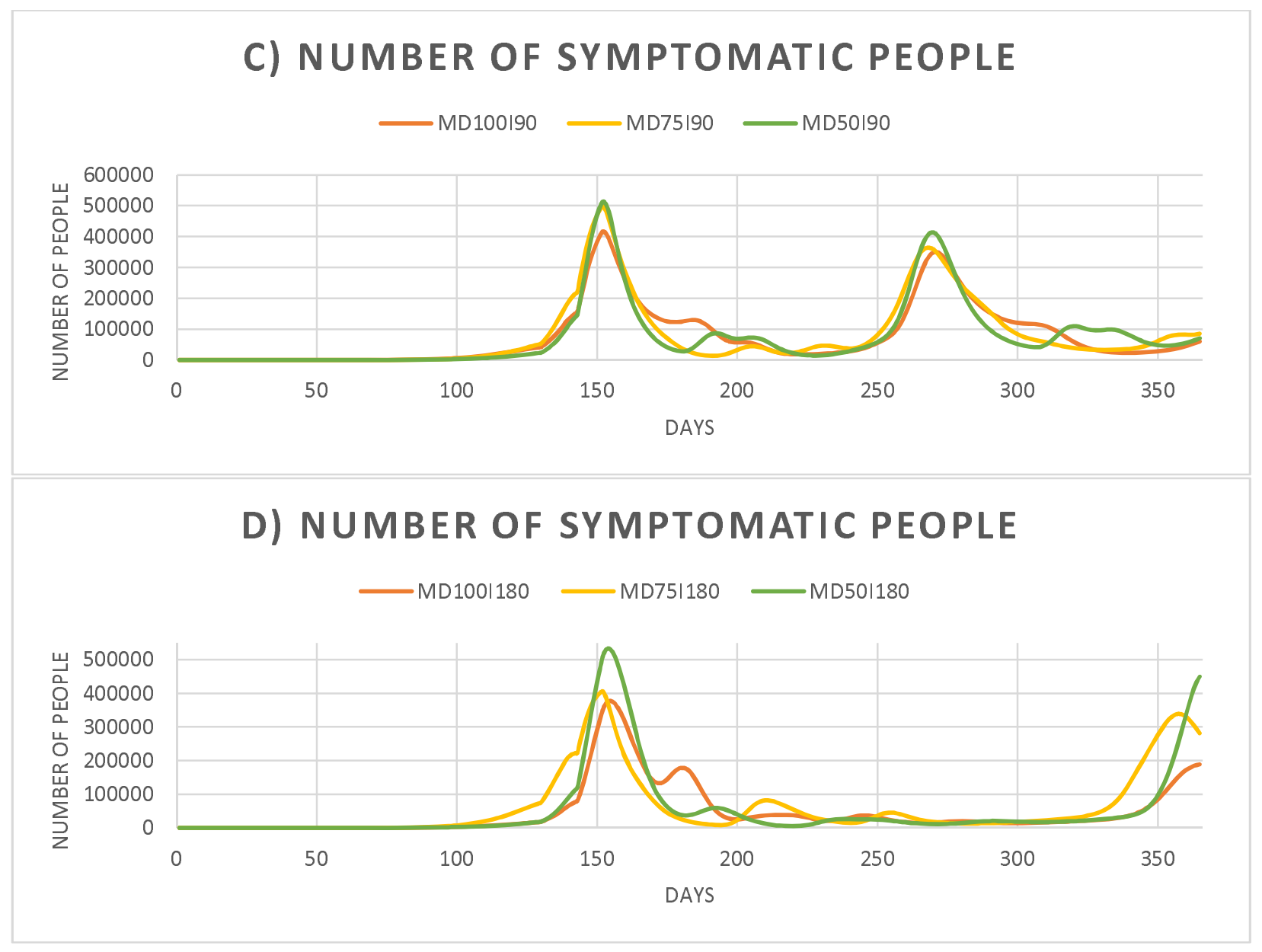

Figure 3 a): Number of Asymptomatic people (90 days immunity scenarios); b) Number of Asymptomatic people (180 days immunity scenarios); c): Number of Symptomatic people (90 days immunity scenarios); b) Number of Symptomatic people (180 days immunity scenarios)

In figures $3 \mathrm{a}$ ), b), c) and d), it is evident that the infection has begun to rise as the lockdown is lifted. The second spike in figures 3 a) and c) indicates the secondary infection which is because of the loss of immunity among recovered people. The same phenomena can be observed to have just begun at the end of one year in figures $3 \mathrm{~b}$ ) and d). Though control measures do not curtail the spread of infection as effectively as lockdown, it offers a level of protection, reducing risk. This is evident from the above figures where the peak values are lesser for the scenarios in which higher proportion of people follow control measures. 
medRxiv preprint doi: https://doi.org/10.1101/2020.10.03.20206177; this version posted October 19, 2020. The copyright holder for this preprint (which was not certified by peer review) is the author/funder, who has granted medRxiv a license to display the preprint in perpetuity.

It is made available under a CC-BY-NC-ND 4.0 International license.

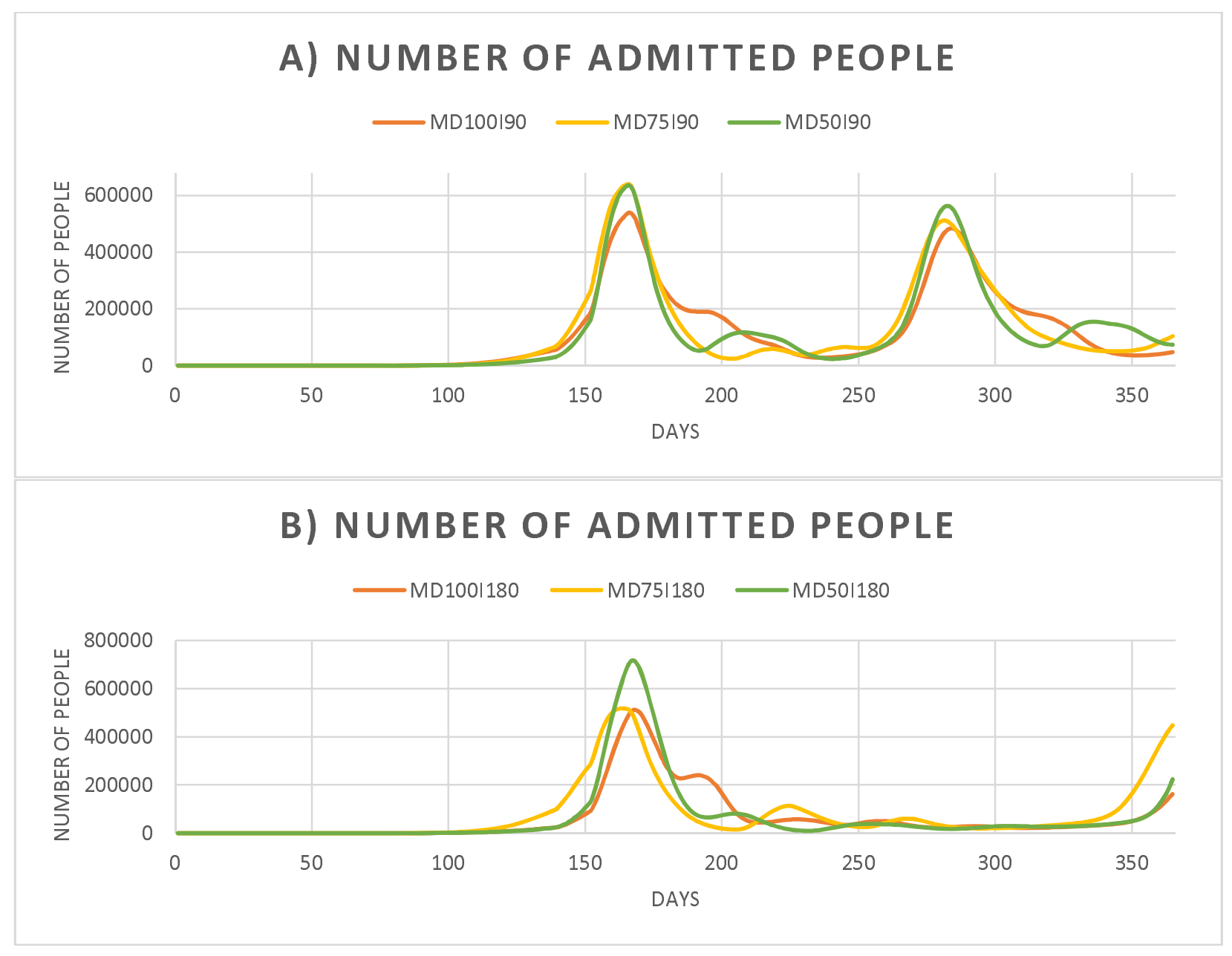


medRxiv preprint doi: https://doi.org/10.1101/2020.10.03.20206177; this version posted October 19,2020 . The copyright holder for this preprint (which was not certified by peer review) is the author/funder, who has granted medRxiv a license to display the preprint in perpetuity.

It is made available under a CC-BY-NC-ND 4.0 International license .

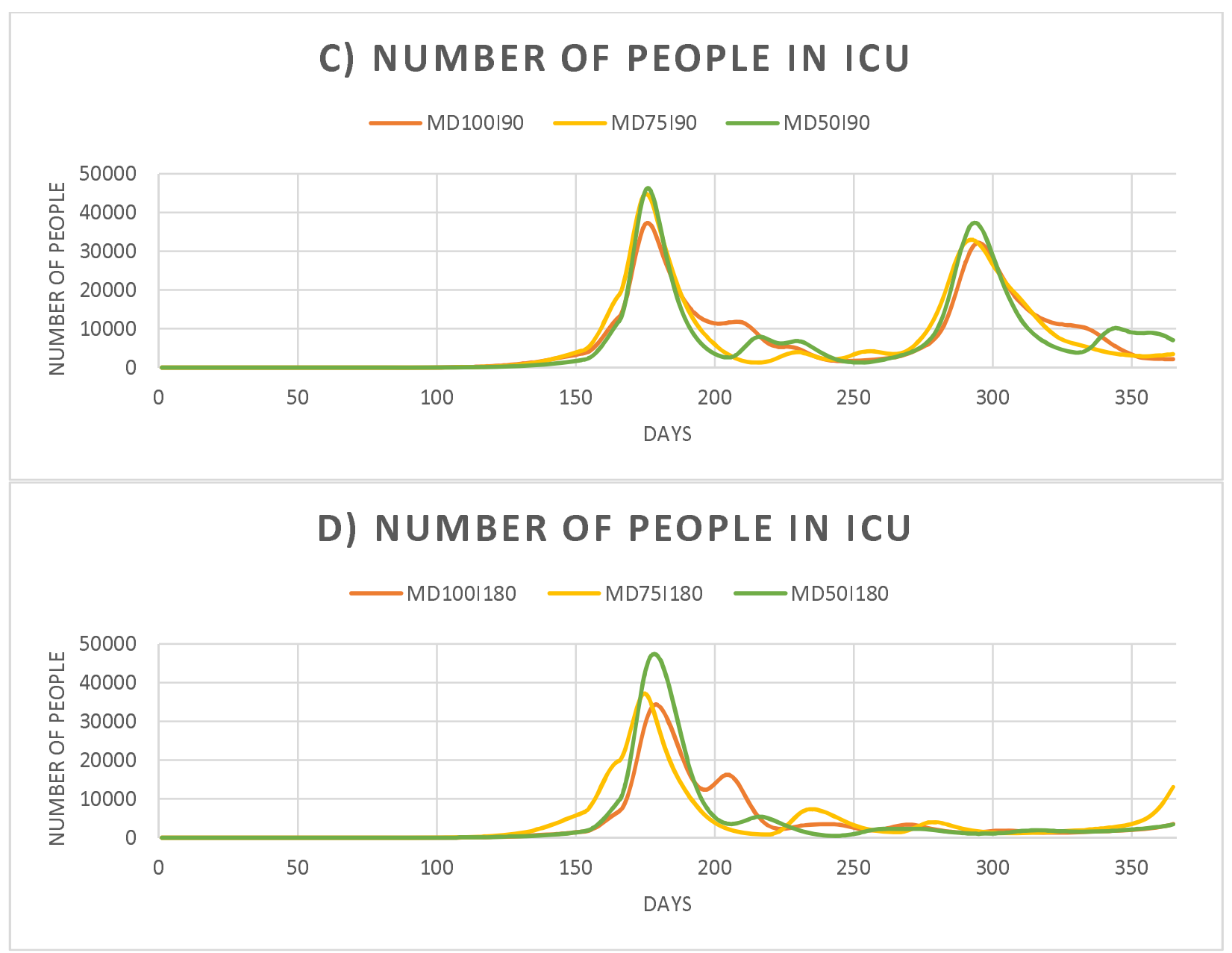




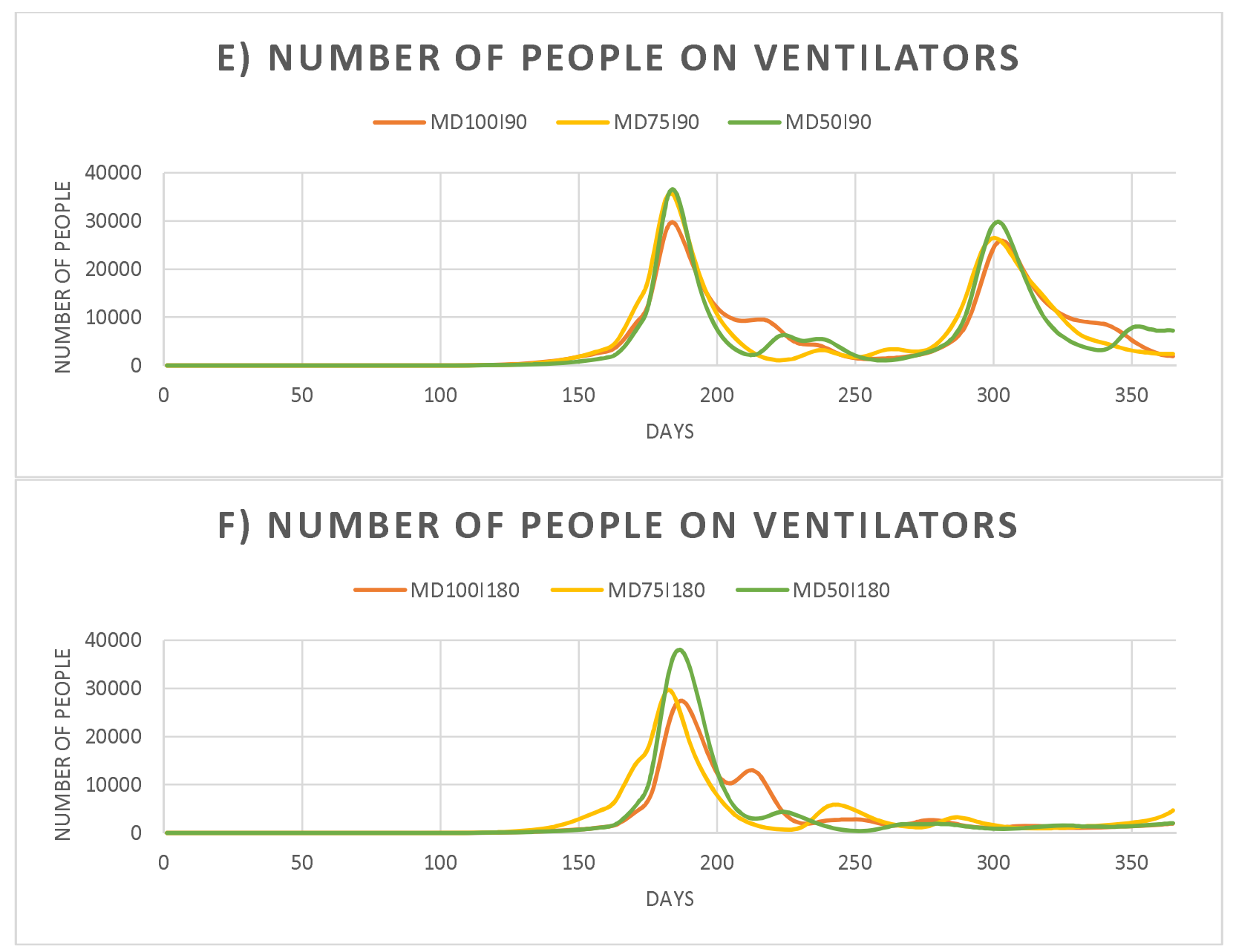

Figure 4 a): Number of Admitted people (90 days immunity scenarios); b) Number of Admitted people (180 days immunity scenarios); c): Number of people in ICU (90 days immunity scenarios); b) Number of people in ICU (180 days immunity scenarios); e) Number of people on Ventilators (90 days immunity scenarios); b) Number of people on Ventilators (180 days immunity scenarios)

From figures 4 a), b) c), d), e) and f), we can observe that there is always a second influx of admissions possible in absence of vaccination. These graphs provide information that could help policymakers, health care system and government to plan their capacity to accommodate the patients and make arrangements for intensive care and ventilators. Similar observations as in figure 3 are observed in terms of secondary infections post loss of immunity of people. 
medRxiv preprint doi: https://doi.org/10.1101/2020.10.03.20206177; this version posted October 19,2020 . The copyright holder for this preprint (which was not certified by peer review) is the author/funder, who has granted medRxiv a license to display the preprint in perpetuity.

It is made available under a CC-BY-NC-ND 4.0 International license .

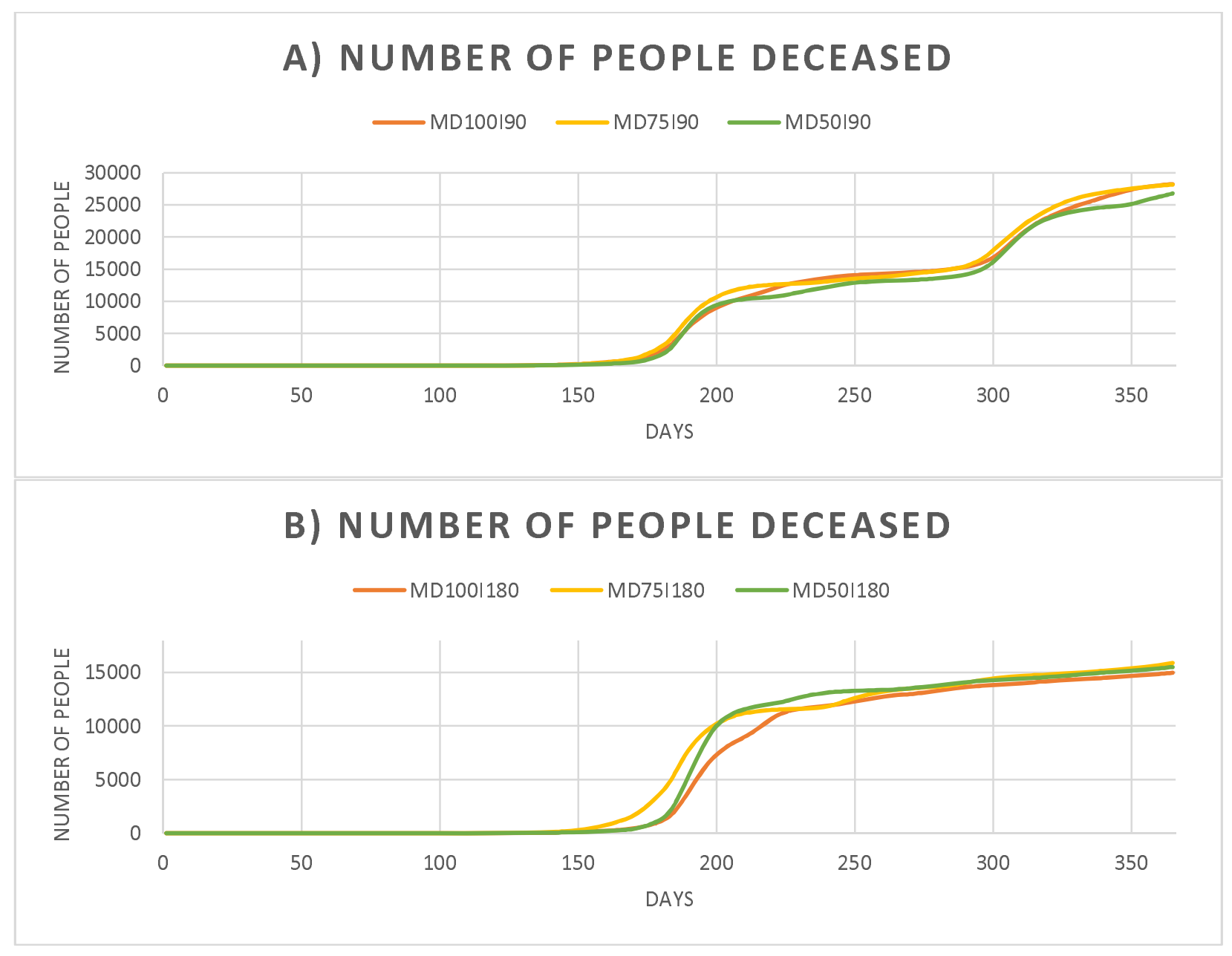




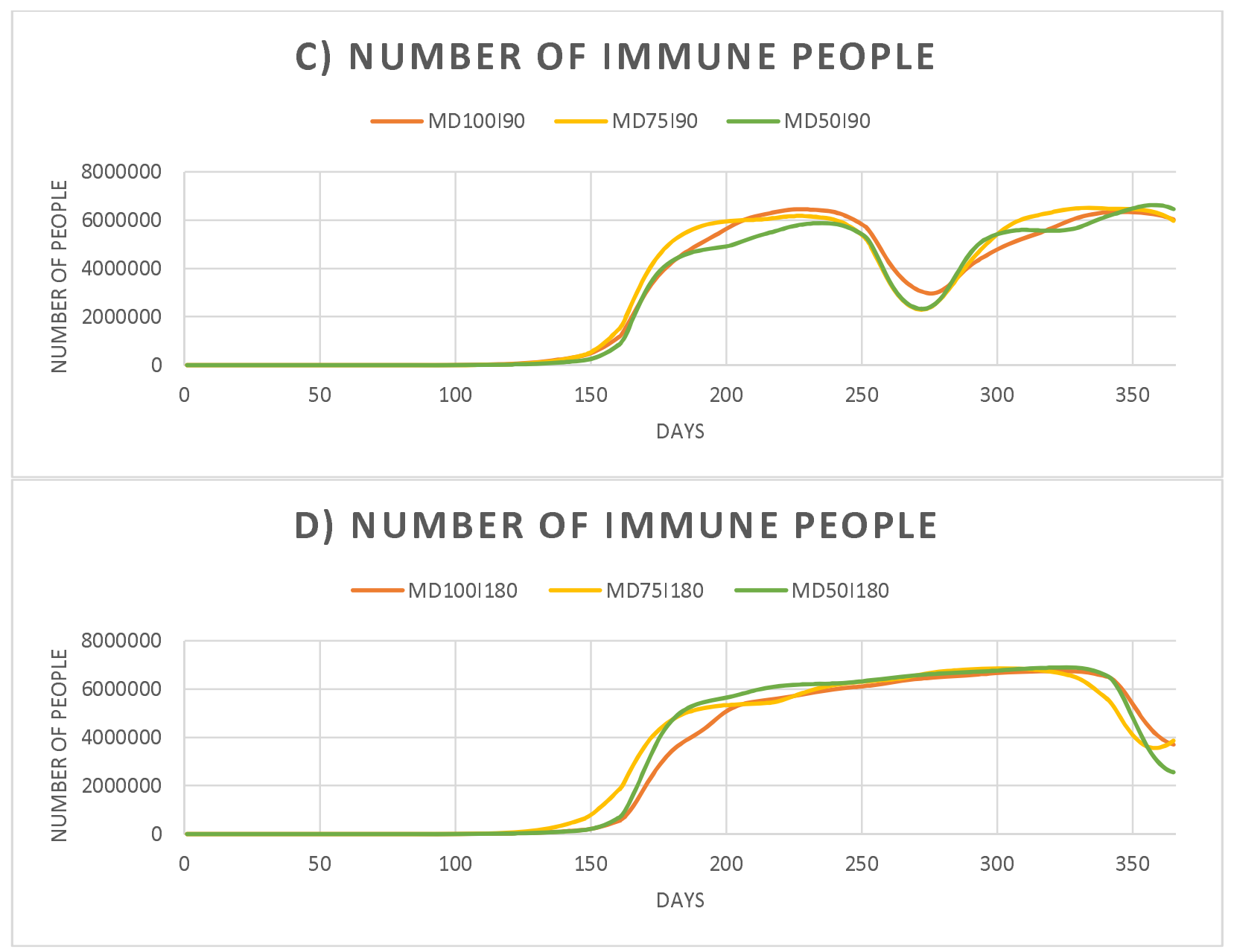

Figure 5 a): Number of Deceased people (90 days immunity scenarios); b) Number of Deceased people (180 days immunity scenarios); c): Number of Immune people (90 days immunity scenarios); b) Number of Immune people (180 days immunity scenarios)

Figures 5 a) and b) represent the number of deceased people. The spike in this number is observed post-lockdown and an additional spike is observed in 5 a) indicating the second influx of infections. This can be directly related to the loss of immunity that is seen in figures $5 \mathrm{c}$ ) and d). Longer immunity offers the health care systems more time to devise vaccination strategies and capacity planning. 
medRxiv preprint doi: https://doi.org/10.1101/2020.10.03.20206177; this version posted October 19,2020 . The copyright holder for this preprint (which was not certified by peer review) is the author/funder, who has granted medRxiv a license to display the preprint in perpetuity.

It is made available under a CC-BY-NC-ND 4.0 International license .

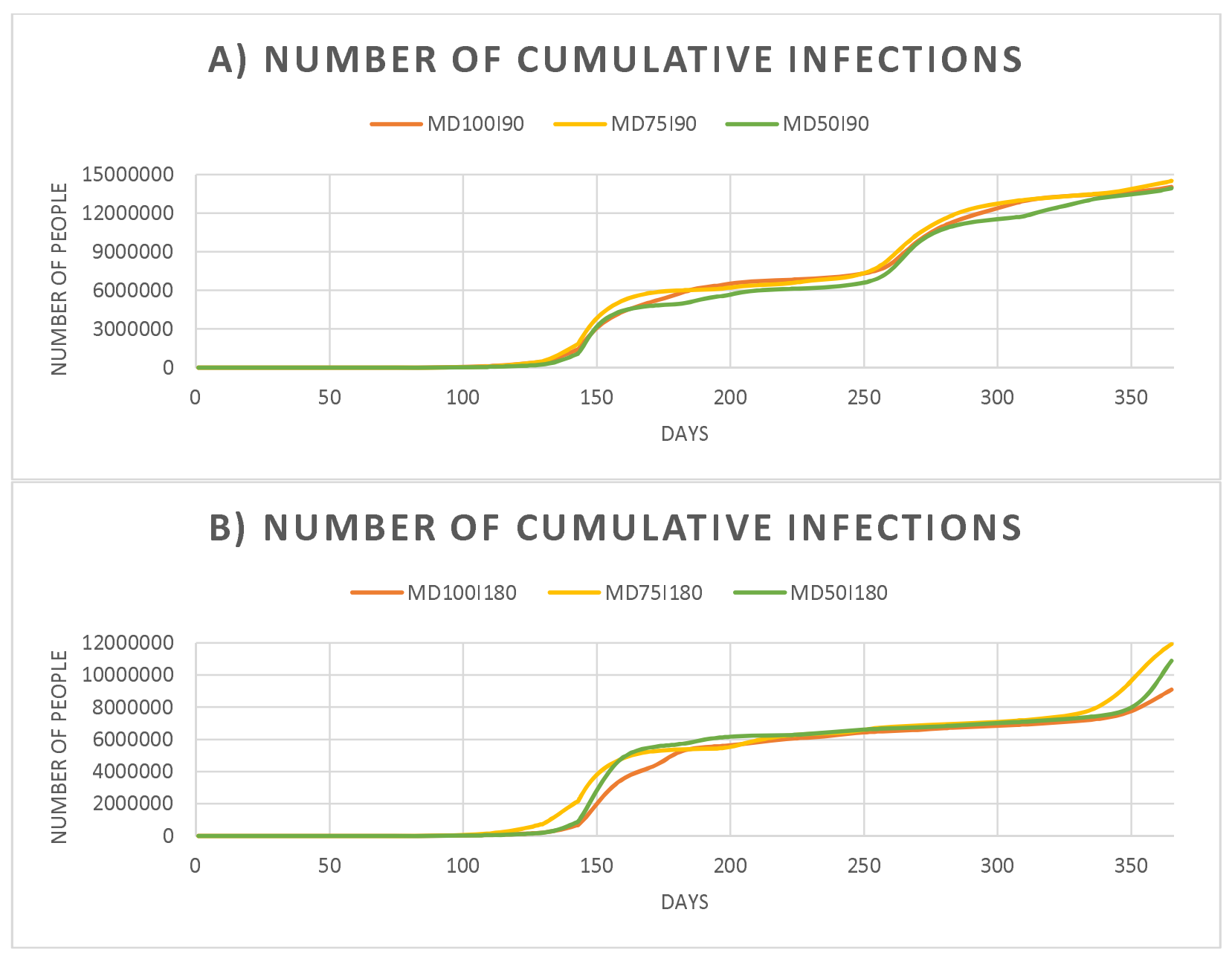




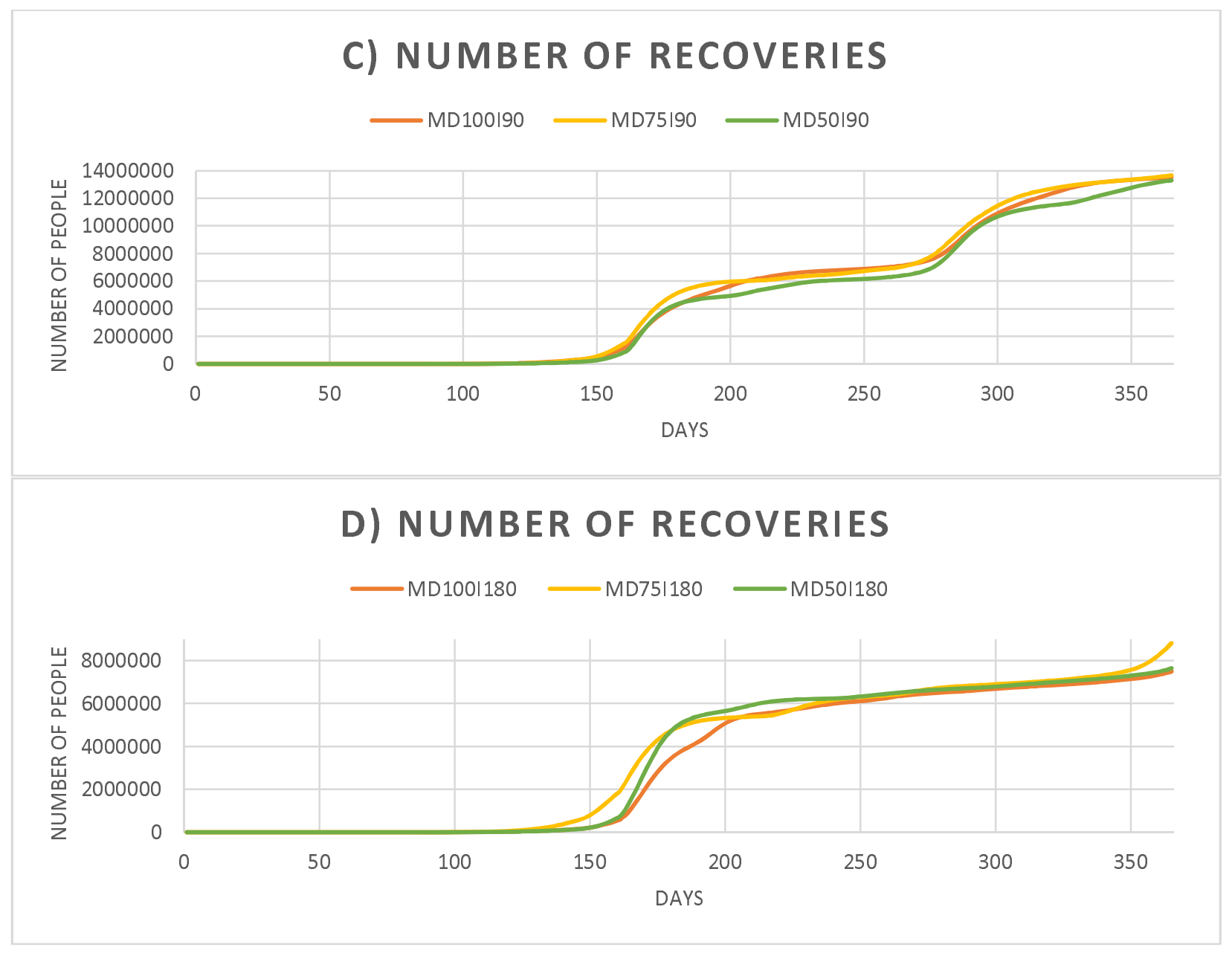

Figure 6 a): Number of Cumulative infections (90 days immunity scenarios); b) Number of Cumulative infections (180 days immunity scenarios); c): Number of Recoveries (90 days immunity scenarios); b) Number of Recoveries (180 days immunity scenarios)

The trends in which the curves of figures 5 a), b), and 6 a), b), c) and d) move are all similar with a time-offset denoting the time in which people stay in each of the intermediate states. Though most of the patients recover, major proportion of people being asymptomatic remains a great challenge for contact tracing and isolation. To measure the protection offered by the lockdown and use of control measures, Relative Risk (RR), Attributable Risk (AR), Population Attributable Risk (PAR) and PAR \% were determined for the various scenarios (table 4). The first time period of 104 days indicates the time period after which the first recovered person would lose immunity. Successively, these parameters are calculated for further time periods to analyze how they vary for different lockdown scenarios [35; 41]. 
Table 4: Risk estimations

\begin{tabular}{|c|c|c|c|c|c|c|c|}
\hline \multirow[b]{2}{*}{$\begin{array}{l}\text { Duration } \\
\text { (days) }\end{array}$} & \multirow[b]{2}{*}{ Scenario } & \multicolumn{2}{|c|}{$\begin{array}{c}\text { Number of people infected } \\
\text { (In a time period) }\end{array}$} & \multirow[b]{2}{*}{$\begin{array}{l}\text { Relative Risk (95\% } \\
\text { CI) }\end{array}$} & \multirow[b]{2}{*}{$\begin{array}{l}\text { Attributable Risk (AR) } \\
\text { (95\% CI) }\end{array}$} & \multirow{3}{*}{ PAR } & \multirow{3}{*}{ PAR \% } \\
\hline & & $\begin{array}{c}\text { Non- } \\
\text { Intervention } \\
\text { (unexposed) }\end{array}$ & $\begin{array}{c}\text { Using } \\
\text { preventive } \\
\text { measures } \\
\text { (exposed) }\end{array}$ & & & & \\
\hline & MD100I90 & 2554 & 69371 & NA & NA & & \\
\hline & MD75I90 & 21310 & 31228 & $0.4885(0.4711,0.5059)$ & $-0.0014(-0.001433,-0.001367)$ & -0.001 & -60.4101 \\
\hline & MD50I90 & 20348 & 14235 & $0.6996(0.6782,0.721)$ & $-0.0004(-0.000423,-0.000377)$ & -0.0002 & -18.3548 \\
\hline & MD100I180 & 2100 & 33437 & NA & NA & & \\
\hline & MD75I180 & 32016 & 55428 & $0.5771(0.5634,0.5908)$ & $-0.0017(-0.001742,-0.001658)$ & -0.0013 & -47.1842 \\
\hline \multirow[t]{6}{*}{0 to 104} & MD50I180 & 19685 & 12586 & $0.6394(0.617,0.6618)$ & $-0.0004(-0.000422,-0.000378)$ & -0.0002 & -19.6698 \\
\hline & MD100I90 & 0 & 6547839 & NA & NA & & \\
\hline & MD75I90 & 1938398 & 4330703 & $0.7447(0.7432,0.7462)$ & $-0.0624(-0.06272,-0.06208)$ & -0.0468 & -23.6932 \\
\hline & MD50I90 & 3266488 & 2541571 & $0.7781(0.7766,0.7796)$ & $-0.0457(-0.045969,-0.045431)$ & -0.0228 & -12.4591 \\
\hline & MD100I180 & 0 & 5668435 & NA & NA & & \\
\hline & MD75I180 & 1693952 & 3907223 & $0.7689(0.7673,0.7705)$ & $-0.0493(-0.049606,-0.048994)$ & -0.037 & -20.9655 \\
\hline \multirow[t]{6}{*}{105 to 204} & MD50I180 & 3382489 & 2782060 & $0.8225(0.8211,0.8239)$ & $-0.0378(-0.038075,-0.037525)$ & -0.0189 & -9.7307 \\
\hline & MD100I90 & 0 & 5999937 & NA & NA & & \\
\hline & MD75I90 & 1841228 & 4716186 & $0.8538(0.8523,0.8553)$ & $-0.0339(-0.034225,-0.033575)$ & -0.0254 & -12.2937 \\
\hline & MD50I90 & 3332683 & 2445789 & $0.7339(0.7324,0.7354)$ & $-0.0559(-0.056169,-0.055631)$ & -0.0279 & -15.3241 \\
\hline & MD100I180 & 0 & 1171268 & NA & NA & & \\
\hline & MD75I180 & 427366 & 1008006 & $0.7862(0.7827,0.7897)$ & $-0.0115(-0.011667,-0.011333)$ & -0.0086 & -19.0159 \\
\hline 205 to 304 & MD50I180 & 544102 & 297366 & $0.5465(0.5421,0.5509)$ & $-0.0155(-0.015612,-0.015388)$ & -0.0078 & -29.4198 \\
\hline
\end{tabular}

The RR values in table 4 indicate that they are estimates of a protective factor as they are less than 1 [41]. The values of RR increase with time owing to the relaxation in lockdown that reduces the protection. Also, the RR values of MD75I90 are lower than those of MD50I90 for the first two time periods indicating the higher protection levels offered when more percentage of people follow control measures. The values of AR and 
$\mathrm{PAR} \%$ also indicate that the protection offered is higher when the lockdowns are more stringent. Also, for a specific time instant, the PAR values are higher for MD75I90 scenarios than for MD50I90 for the first two time periods.

Table 5: Peak values

\begin{tabular}{|c|c|c|c|c|c|c|c|c|c|c|c|c|}
\hline \multirow{2}{*}{$\begin{array}{c}\text { Peak values/ } \\
\text { Scenarios }\end{array}$} & \multicolumn{2}{|c|}{ MD100I90 } & \multicolumn{2}{|c|}{ MD75I90 } & \multicolumn{2}{|c|}{ MD50I90 } & \multicolumn{2}{|c|}{ MD100I180 } & \multicolumn{2}{|c|}{ MD75I180 } & \multicolumn{2}{|c|}{ MD50I180 } \\
\hline & Value & Day & Value & Day & Value & Day & Value & Day & Value & Day & Value & Day \\
\hline Healthy & 31738202 & 1 & 31738208 & 1 & 31738204 & 1 & 31738208 & 1 & 31738200 & 1 & 31738206 & 1 \\
\hline Asymptomatic & 2491332 & 160 & 2950047 & 157 & 2842052 & 158 & 2416859 & 161 & 2440704 & 154 & 3341037 & 161 \\
\hline Symptomatic & 416618 & 152 & 498176 & 152 & 513427 & 152 & 377067 & 155 & 405197 & 152 & 532776 & 154 \\
\hline Infected & 2782185 & 157 & 3353298 & 155 & 3236504 & 155 & 2709667 & 161 & 2830878 & 152 & 3729075 & 160 \\
\hline Admitted & 538683 & 166 & 639556 & 166 & 634877 & 166 & 511264 & 168 & 516807 & 164 & 715501 & 167 \\
\hline ICU & 37256 & 176 & 44739 & 175 & 46224 & 176 & 34393 & 179 & 37176 & 175 & 47353 & 178 \\
\hline Ventilator & 29641 & 184 & 35580 & 183 & 36589 & 184 & 27389 & 187 & 29574 & 183 & 37891 & 186 \\
\hline Immune & 6443023 & 228 & 6508198 & 333 & 6620998 & 358 & 6724187 & 323 & 6853529 & 302 & 6895030 & 325 \\
\hline
\end{tabular}

It is clear that the peak infections in all scenarios occur in a few days after lifting of lockdown on 143rd day. It is also observed that the peak values of infected, admitted, ICU, and ventilator are the least for the scenarios where 100 percent of the population follow the control measures.

\section{Sensitivity Analysis}

The dynamics of pandemic that has been changing consistently is making the scenario challenging for the healthcare fraternity and policymakers. In India, recent studies have reported prolonged incubation period with a mean of 6.93 days [59] and the proportion of asymptomatic infections to be 91 percent [45]. Sensitivity analysis has been conducted to examine the effects of these changes on the disease transmission. Various scenarios of sensitivity analysis contain notations in which the numbers succeeding ' $I$ ' and 'A' indicate incubation period (days) and the proportion of asymptomatic people respectively.

Table 6: Results of Sensitivity Analysis

\begin{tabular}{|c|c|c|c|c|c|c|c|c|c|}
\hline \multicolumn{2}{|l|}{ Scenario } & \multicolumn{4}{|c|}{ MD100I180 } & \multicolumn{4}{|c|}{ MD100I90 } \\
\hline \multicolumn{2}{|c|}{ Incubation period (days) } & 5 & 7 & 5 & 7 & 5 & 7 & 5 & 7 \\
\hline \multicolumn{2}{|c|}{ Asymptomatic proportion (\%) } & \multicolumn{2}{|c|}{80} & \multicolumn{2}{|c|}{91} & \multicolumn{2}{|c|}{80} & \multicolumn{2}{|c|}{91} \\
\hline & Asymptomatic & 27813 & 15740 & 22948 & 19367 & 22532 & 57773 & 10058 & 59146 \\
\hline & Symptomatic & 3913 & 853 & 3633 & 1120 & 3070 & 3038 & 1661 & 3494 \\
\hline & Infected & 31726 & 16577 & 26581 & 20487 & 25602 & 60719 & 11719 & 62640 \\
\hline & Admitted & 4763 & 1129 & 3516 & 1259 & 4247 & 4528 & 1495 & 3909 \\
\hline & $\mathrm{ICU}$ & 240 & 66 & 153 & 79 & 205 & 296 & 68 & 224 \\
\hline & Ventilator & 149 & 44 & 111 & 51 & 159 & 224 & 52 & 170 \\
\hline & Deceased & 78 & 30 & 46 & 21 & 62 & 138 & 33 & 91 \\
\hline Peak Values (Adilabad) & Immune & 60697 & 40220 & 42129 & 45926 & 53503 & 208549 & 20893 & 135934 \\
\hline \multicolumn{2}{|c|}{ Cumulative Infected } & 97717 & 58133 & 72580 & 67891 & 85969 & 293065 & 37802 & 211521 \\
\hline & Asymptomatic & 57770 & 77505 & 93479 & 103439 & 51512 & 93971 & 92222 & 44920 \\
\hline & Symptomatic & 7782 & 4129 & 13971 & 6234 & 7266 & 4979 & 13412 & 2526 \\
\hline & Infected & 65408 & 81550 & 107112 & 109360 & 58778 & 98927 & 105503 & 47343 \\
\hline & Admitted & 11447 & 6097 & 17249 & 7586 & 8664 & 7420 & 16647 & 3109 \\
\hline & $\mathrm{ICU}$ & 739 & 389 & 1127 & 476 & 535 & 475 & 1029 & 201 \\
\hline Peak Values (Rangareddy) & Ventilator & 614 & 325 & 897 & 377 & 436 & 394 & 842 & 169 \\
\hline
\end{tabular}


medRxiv preprint doi: https://doi.org/10.1101/2020.10.03.20206177; this version posted October 19, 2020. The copyright holder for this preprint (which was not certified by peer review) is the author/funder, who has granted medRxiv a license to display the preprint in perpetuity.

It is made available under a CC-BY-NC-ND 4.0 International license .

\begin{tabular}{crrrrrrrrr}
\hline Deceased & 568 & 348 & 660 & 314 & 499 & 355 & 859 & 220 \\
Immune & 266573 & 322618 & 331234 & 341029 & 187072 & 346472 & 354727 & 188777 \\
Cumulative Infected & 274825 & 328524 & 331234 & 368414 & 348583 & 436828 & 565900 & 307029 \\
\hline
\end{tabular}
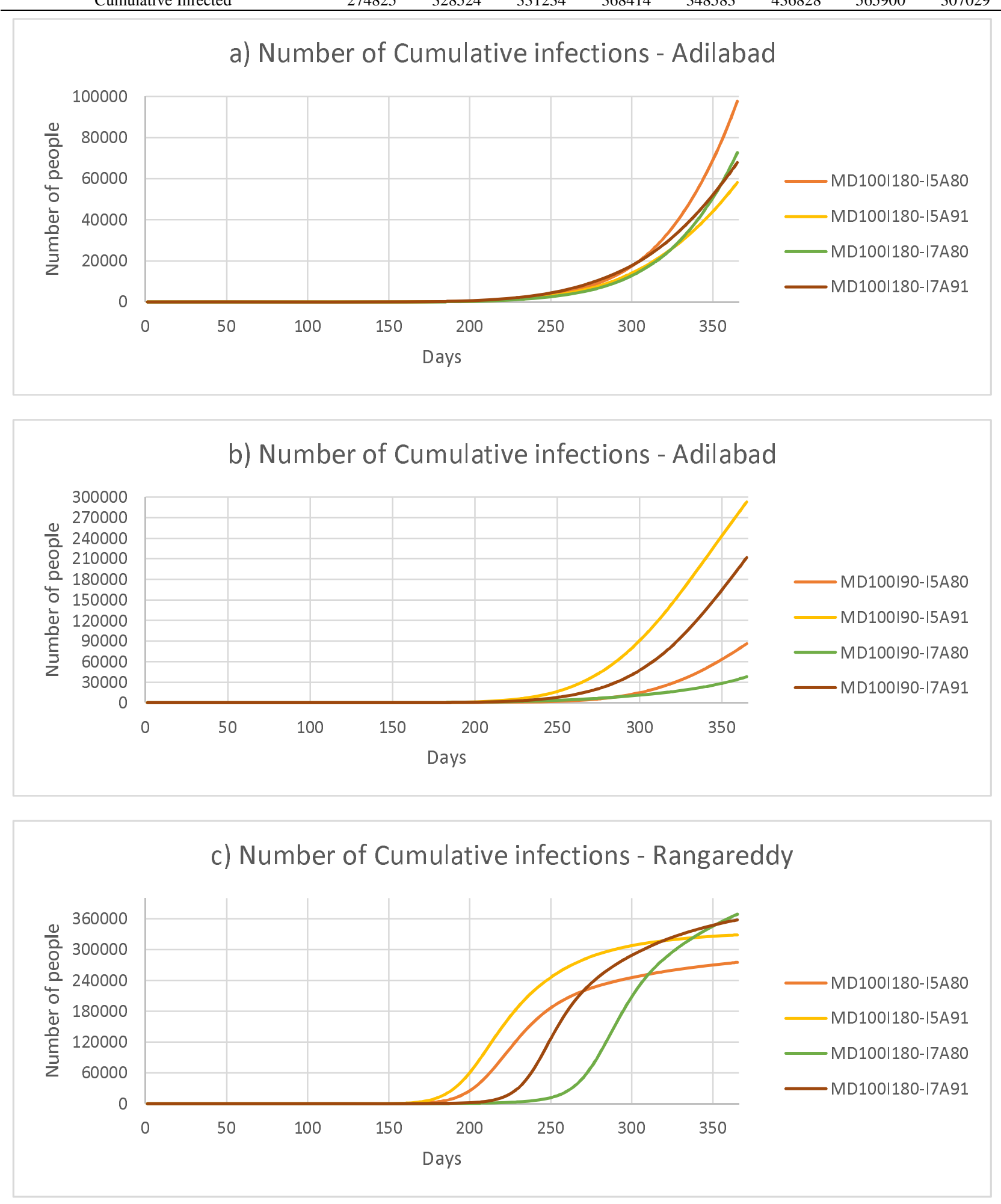


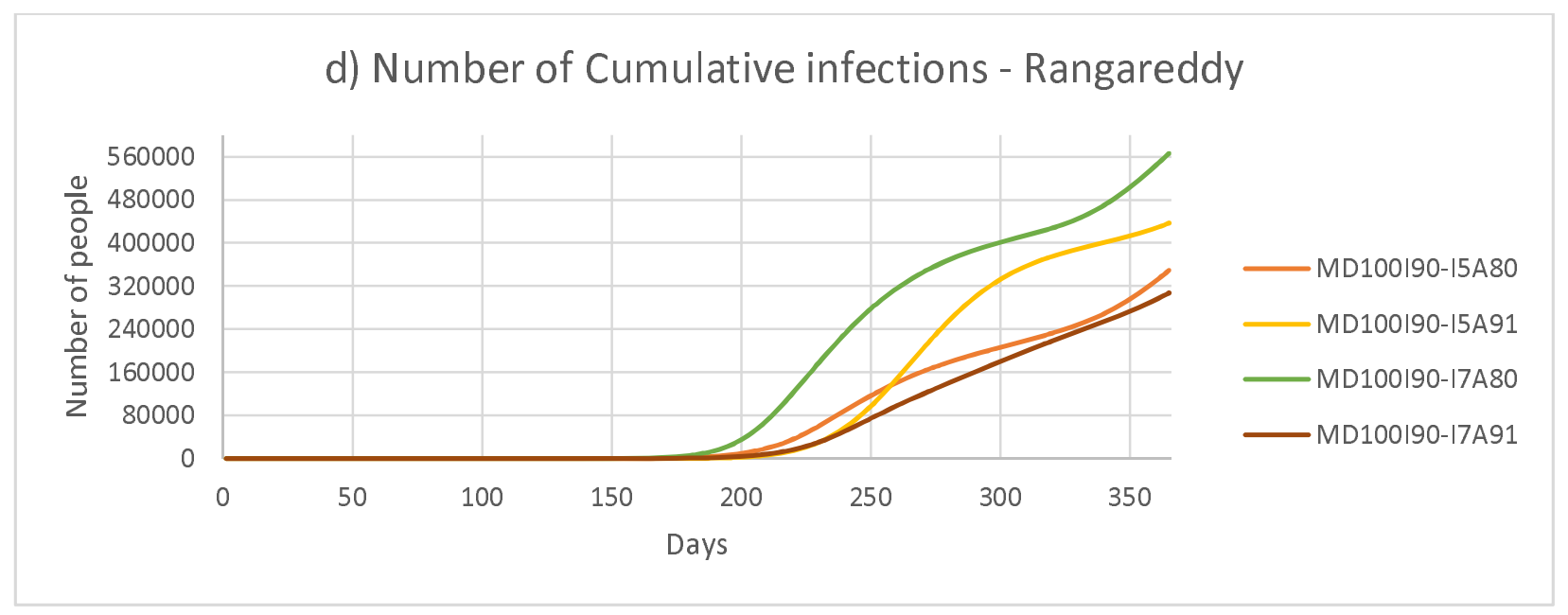

Figure 7: a) Number of Cumulative infections - Adilabad, b) Number of Cumulative infections - Adilabad, c) Number of Cumulative infections - Rangareddy, d) Number of Cumulative infections - Rangareddy

Results in table 6 depict that the spread is relatively higher in Rangareddy compared to Adilabad, which is due to the higher population density of the district. Cumulative infections in most of the scenarios are higher when the incubation period is 7 days. This is because of the additional days in which infected people transmit infection. Also, in scenarios wherein asymptomatic proportion is considered to be 91 percent, the admissions are less because symptomatic people are only considered to be admitted whilst asymptomatic people are assumed to recover without being treated in hospitals. More asymptomatic carriers highly increase the spread of infection. Increasing testing, contact tracing, etc., and pitching in NPIs to track the close contacts of infected people might help to curtail the infection. The results of figure 6 also complements the fact that as the asymptomatic proportion and/ or incubation period increase,

the

spread

of

infection

increases 


\section{Discussion}

The present study simulated 31738240 valid agents representing $90.67 \%$ of Telangana population for six different scenarios considering the various phases of lockdown as was imposed in India. The study also measures the effect of use of control measures and role of immunity in the spread of infection. This places policymakers in a better position to take decisions locally [10]. District level parameters have been considered to run the simulation along with assignment of agent-level details such as age, geospatial locations, etc. The model description, results, and discussion are inline with ethical good practice in modelling and ISPOR-SMDM Modeling Good Research Practices.

Present study involves modeling of six different scenarios with varying proportions of people using control measures $(100 \%, 75 \%$ and 50\%) and varying immunity periods of recovered patients (90 and 180 days). Likewise, several other studies have modeled different types of scenarios. Most of the studies revolve around imposing lockdowns whilst varying the durations of lockdown [37], isolating vulnerable population [37], varying lockdown stringency based on age [36], changing proportions of contacts made outside household and close contacts [40], considering contact tracing measures [36; 68], etc.

In this study, we have developed the agents from the 2011 Census of India data with 31738240 valid agents representing 90.67 percent of Telangana's population [57; 70]. Number of people in each of the states have been determined based on parameters of each district as localized models are much preferred for decision-making. Synthetic population approach that is widely employed use open data sources like the Australian Census data [64], US Census data [36; 40], London Imperial College data [37], etc. Various geolocations have been represented previously using different number of agents such as 5000 agents in a University of Italy [21], 500000 agents of NYC [36], 24 million agents of entire Australian population [64], 750805 agents of Urmia, Iran [51], 10 million agents of Delaware, US [40], etc.

Contact network influences the behavior of agents in the network. Present study has considered contacts made in closest circle and external places as mentioned in table 3. As the stringency of lockdown is increased, the overall contact rate decreases whereas the proportion of contacts made in closer circle and households increase. Different studies have considered a range of contact network settings such as contacts in closed environments as offices, colleges, contacts based on schedules [36; 40;68], indirect transmission through viral particles [40], touching of contaminated objects, enhancing protection by washing hands [20;43; 68], inclusion of travel medium and routes [27; 60], transmission in public places [40], etc.

From the results, it is clear that the rate of transmission of infection increased as the lockdowns were lifted and the peak infections were observed in a lesser number of days post-lockdown. Also, the values of RR, AR, PAR\% indicate that the protection factor had higher values during lockdown and when a higher number of people followed control measures. The values of AR, RR and PAR\% help in determining the protection offered, strength, and percent of population that could attribute to the protection factor [41]. Effect of immunity also provides information about possible secondary infections post loss of immunity. This assists the capacity planning of health care practitioners and policymakers. Complementing this is the study by The Center For Disease Dynamics, Economics \& Policy (CDDEP) and Princeton University where they have provided state-wise estimates across India to assist policymakers to cope up with the influx of infections [42; 73].

Limitations to the study include the exclusion of comorbidities among patients, transportation modes, indirect transmission through suspended particles, etc., which could be considered to improve the accuracy of the model. Considering more parameters are however limited to the availability and authenticity of data.

\section{Conclusions}

We have modeled the COVID-19 transmission dynamics considering the various lockdown phases of India using an ABM approach using Python, an open source coding platform. Localized studies such as this, based on synthetic populations could be helpful in decision-making processes of localized authorities. Important factors such as protective factor could provide insights on the proportion of population that would be shielded by imposing control measures. 
medRxiv preprint doi: https://doi.org/10.1101/2020.10.03.20206177; this version posted October 19, 2020. The copyright holder for this preprint (which was not certified by peer review) is the author/funder, who has granted medRxiv a license to display the preprint in perpetuity.

It is made available under a CC-BY-NC-ND 4.0 International license .

\section{Data Availability}

The python code, and detailed district-wise estimates files are available in the link: https://osf.io/3nxby/?view_only=96320e1dd7f048318294898ccd657275

\section{Conflicts of Interest}

The authors declare that there is no conflict of interest regarding the publication of this article.

\section{Funding information}

No funds were received for conducting this modeling study.

\section{References}

[1] Abu-Rayash, A., \& Dincer, I. (2020). Analysis of mobility trends during the COVID-19 coronavirus pandemic: Exploring the impacts on global aviation and travel in selected cities. Energy Research and Social Science, 68(July), 101693. https://doi.org/10.1016/j.erss.2020.101693

[2] Ambikapathy, B., \& Krishnamurthy, K. (2020). Mathematical modelling to assess the impact of lockdown on COVID-19 transmission in India: Model development and validation. Journal of Medical Internet Research, 22(5), 1-8. https://doi.org/10.2196/19368

[3] Arentz, M., Yim, E., Klaff, L., Lokhandwala, S., Riedo, F. X., Chong, M., \& Lee, M. (2020). Characteristics and Outcomes of 21 Critically Ill Patients with COVID-19 in Washington State. JAMA - Journal of the American Medical Association, 323(16), 1612-1614. https://doi.org/10.1001/jama.2020.4326

[4] Auchincloss, A. H., \& Garcia, L. M. T. (2015). Brief introductory guide to agent-based modeling and an illustration from urban health research. Cadernos de Saúde Pública, 31(suppl 1), 65-78. https://doi.org/10.1590/0102-311x00051615

[5] Aylward, Bruce (WHO); Liang, W. (PRC). (2020). Report of the WHO-China Joint Mission on Coronavirus Disease 2019 (COVID-19). In The WHO-China Joint Mission on Coronavirus Disease 2019. https://www.who.int/docs/default-source/coronaviruse/who-china-joint-mission-on-covid-19-final-report.pdf

[6] Badham, J., Chattoe-Brown, E., Gilbert, N., Chalabi, Z., Kee, F., \& Hunter, R. F. (2018). Developing agentbased models of complex health behaviour. Health and Place, 54(January), 170-177. https://doi.org/10.1016/j.healthplace.2018.08.022

[7] Bai, R.-H., Dong, W.-Y., Shi, Y., Feng, A.-Z., Xu, A.-D., \& Lyu, J. (2020). Simulation of epidemic trends for a new coronavirus under effective control measures. New Medicine, 30(2), 8-12. https://doi.org/10.12173/j.issn.1004-5511.2020.02.03

[8] Balk, D., Montgomery, M. R., Engin, H., Lin, N., Major, E., \& Jones, B. (2019). Urbanization in India: Population and urban classification grids for 2011. Data, 4(1), 1-16. https://doi.org/10.3390/data4010035

[9] Boden, L. A., \& McKendrick, I. J. (2017). Model-based policymaking: A framework to promote ethical "good practice" in mathematical modeling for public health policymaking. Frontiers in Public Health, 5(APR), 1-7. https://doi.org/10.3389/FPUBH.2017.00068

[10] Caro, J. J., Briggs, A. H., Siebert, U., \& Kuntz, K. M. (2012). Modeling Good Research Practices-Overview: A Report of the ISPOR-SMDM Modeling Good Research Practices Task Force-1. 15(6), 796-803. https://doi.org/10.1177/0272989X12454577

[11] Chan, W. K. V., Son, Y. J., \& Macal, C. M. (2011). Agent-based simulation tutorial - Simulation of emergent behavior and differences between agent-based simulation and discrete-event simulation. Proceedings of the 2010 Winter Simulation Conference. https://doi.org/10.1109/WSC.2010.5679168

[12] Chang, S. L., Harding, N., Zachreson, C., Cliff, O. M., \& Prokopenko, M. (2020). Modelling transmission and control of the COVID-19 pandemic in Australia. ArXiv Preprint ArXiv:2003.10218. 2020 Mar 23., 1-31. http://arxiv.org/abs/2003.10218

[13] Chatterjee, K., Chatterjee, K., Kumar, A., \& Shankar, S. (2020). Healthcare impact of COVID-19 epidemic in India: A stochastic mathematical model. Medical Journal Armed Forces India, 76(2), 147-155. 
https://doi.org/10.1016/j.mjafi.2020.03.022

[14] Chu, D. K., Akl, E. A., Duda, S., Solo, K., Yaacoub, S., Schünemann, H. J., El-harakeh, A., Bognanni, A., Lotfi, T., Loeb, M., Hajizadeh, A., Bak, A., Izcovich, A., Cuello-Garcia, C. A., Chen, C., Harris, D. J., Borowiack, E., Chamseddine, F., Schünemann, F., ... Reinap, M. (2020). Physical distancing, face masks, and eye protection to prevent person-to-person transmission of SARS-CoV-2 and COVID-19: a systematic review and meta-analysis. The Lancet, 395(10242), 1973-1987. https://doi.org/10.1016/S0140-6736(20)31142-9

[15] Cooley, P., Lee, B. Y., Brown, S., Cajka, J., Chasteen, B., Ganapathi, L., Stark, J. H., Wheaton, W. D., Wagener, D. K., \& Burke, D. S. (2010). Protecting health care workers: A pandemic simulation based on Allegheny County. Influenza and Other Respiratory Viruses, 4(2), 61-72. https://doi.org/10.1111/j.17502659.2009.00122.x

[16] Coronavirus Disease (COVID-19) Situation Reports. (2020). Ministry of Health and Family Welfare (MoHFW). Update Covid-19. https://www.who.int/emergencies/diseases/novel-coronavirus-2019/situationreports/

[17] Coronavirus Outbreak in India - covid19india.org. (2020). https://www.covid19india.org/

[18] COVID-19 pandemic lockdown in India - Wikipedia. (2020). https://en.wikipedia.org/wiki/COVID19_pandemic_lockdown_in_India

[19] Covid-19 risk factors: Age, underlying conditions, genetics, and unknowns - Vox. (n.d.-s). Retrieved August 26, 2020, from https://www.vox.com/science-and-health/2020/4/8/21207269/covid-19-coronavirus-risk-factors

[20] Cuevas, E. (2020). An agent-based model to evaluate the COVID-19 transmission risks in facilities. Computers in Biology and Medicine, 121(April), 103827. https://doi.org/10.1016/j.compbiomed.2020.103827

[21] D’Orazio, M., Bernardini, G., \& Quagliarini, E. (2020). How to restart? An agent-based simulation model towards the definition of strategies for COVID-19 "second phase" in public buildings. ArXiv, 1-21. http://arxiv.org/abs/2004.12927

[22] Day, M. (2020). Covid-19: four fifths of cases are asymptomatic, China figures indicate. BMJ (Clinical Research Ed.), 369(April), m1375. https://doi.org/10.1136/bmj.m1375

[23] Enanoria, W. T. A., Liu, F., Zipprich, J., Harriman, K., Ackley, S., Blumberg, S., Worden, L., \& Porco, T. C. (2016). The effect of contact investigations and public health interventions in the control and prevention of measles transmission: A simulation study. PLoS ONE, 11(12), e0167160. https://doi.org/10.1371/journal.pone.0167160

[24] Epstein, J. M., Pankajakshan, R., \& Hammond, R. A. (2011). Combining computational fluid dynamics and agent-based modeling: A new approach to evacuation planning. PLOS ONE, 6(5), e20139. https://doi.org/10.1371/journal.pone.0020139

[25] Ferguson, N. M., Cummings, D. A. T., Cauchemez, S., Fraser, C., Riley, S., Meeyai, A., Iamsirithaworn, S., \& Burke, D. S. (2005). Strategies for containing an emerging influenza pandemic in Southeast Asia. Nature, 437(7056), 209-214. https://doi.org/10.1038/nature04017

[26] GitHub - thoughtworks/epirust: An agent-based epidemiology simulation framework built in Rust. (n.d.-z). Retrieved August 27, 2020, from https://github.com/thoughtworks/epirust

[27] Gomez, J., Prieto, J., Leon, E., \& Rodriguez, A. (2020). INFEKTA: A General Agent-based Model for Transmission of Infectious Diseases: Studying the COVID-19 Propagation in Bogotá - Colombia. MedRxiv., 115. https://doi.org/10.1101/2020.04.06.20056119

[28] Grasselli, G., Zangrillo, A., Zanella, A., Antonelli, M., Cabrini, L., Castelli, A., Cereda, D., Coluccello, A., Foti, G., Fumagalli, R., Iotti, G., Latronico, N., Lorini, L., Merler, S., Natalini, G., Piatti, A., Ranieri, M. V., Scandroglio, A. M., Storti, E., ... Pesenti, A. (2020). Baseline Characteristics and Outcomes of 1591 Patients Infected with SARS-CoV-2 Admitted to ICUs of the Lombardy Region, Italy. JAMA - Journal of the American Medical Association, 323(16), 1574-1581. https://doi.org/10.1001/jama.2020.5394

[29] Grewal, K. (2020). Swiss cheese model - a combination of "interventions" experts are suggesting to combat Covid. https://theprint.in/health/swiss-cheese-model-a-combination-of-interventions-experts-are-suggesting-tocombat-covid/522499/

[30] Grigoryev, I. (2018). Anylogic in three days: A quick course in simulation modeling (Fifth). The AnyLogic Company. https://www.anylogic.com/resources/books/free-simulation-book-and-modeling-tutorials/

[31] Grimm, V., Berger, U., Bastiansen, F., Eliassen, S., Ginot, V., Giske, J., Goss-Custard, J., Grand, T., Heinz, S. K., Huse, G., Huth, A., Jepsen, J. U., Jørgensen, C., Mooij, W. M., Müller, B., Pe'er, G., Piou, C., Railsback, S. F., Robbins, A. M., ... DeAngelis, D. L. (2006). A standard protocol for describing individual-based and agentbased models. Ecological Modelling, 198(1-2), 115-126. https://doi.org/10.1016/j.ecolmodel.2006.04.023

[32] Grimm, V., Berger, U., DeAngelis, D. L., Polhill, J. G., Giske, J., \& Railsback, S. F. (2010). The ODD protocol: A review and first update. Ecological Modelling, 221(23), 2760-2768. 
https://doi.org/10.1016/j.ecolmodel.2010.08.019

[33] Grimm, V., Revilla, E., Berger, U., Jeltsch, F., Mooij, W. M., Railsback, S. F., Thulke, H. H., Weiner, J., Wiegand, T., \& DeAngelis, D. L. (2005). Pattern-oriented modeling of agent-based complex systems: Lessons from ecology. Science, 310(5750), 987-991. https://doi.org/10.1126/science.1116681

[34] Halloran, M. E., Longini, I. M., Nizam, A., \& Yang, Y. (2002). Containing bioterrorist smallpox. Science, 298(5597), 1428-1432. https://doi.org/10.1126/science.1074674

[35] Handler, A., Rosenberg, D., Kennelly, J., \& Monahan, C. (1998). Analytic methods in maternal and child health (A. Handler, D. Rosenberg, J. Kennelly, \& C. Monahan (Eds.)). University of Illinois at Chicago, School of Public Health.

[36] Hoertel, N., Blachier, M., Blanco, C., Olfson, M., Massetti, M., Limosin, F., \& Leleu, H. (2020). Facing the COVID-19 epidemic in NYC: a stochastic agent-based model of various intervention strategies. MedRxiv. https://doi.org/10.1101/2020.04.23.20076885

[37] Hoertel, N., Blachier, M., Blanco, C., Olfson, M., Massetti, M., Rico, M. S., Limosin, F., \& Leleu, H. (2020). A stochastic agent-based model of the SARS-CoV-2 epidemic in France. Nature Medicine, 26(9), 1417-1421. https://doi.org/10.1038/s41591-020-1001-6

[38] India population 2020 - StatisticsTimes.com. (2020). StatisticsTimes. http://statisticstimes.com/demographics/country/india-population.php

[39] Institute for Disease Modeling. (2020). Population density and transmission scaling - Generic Model documentation. https://idmod.org/docs/emod/generic/model-population-density.html

[40] Jalayer, M., Orsenigo, C., \& Vercellis, C. (2020). CoV-ABM: A stochastic discrete-event agent-based framework to simulate spatiotemporal dynamics of COVID-19. ArXiv. http://arxiv.org/abs/2007.13231

[41] Kahn, M. J., O’Fallon, W. M., \& Sicks, J. D. (2000). Generalized Population Attributable Estimation (p. 72). St. Olaf College, Mayo Clinic and National Institutes of Health, U.S.P.H.S.

[42] Kapoor, G., Hauck, S., Sriram, A., Joshi, J., Schueller, E., Frost, I., Balasubramanian, R., Laxminarayan, R., \& Nandi, A. (2020). State-wise estimates of current hospital beds, intensive care unit (ICU) beds and ventilators in India: Are we prepared for a surge in COVID-19 hospitalizations? MedRxiv, 2020.06.16.20132787. https://doi.org/10.1101/2020.06.16.20132787

[43] Kerr, C. C., Stuart, R. M., Mistry, D., Abeysuriya, R. G., Hart, G., Rosenfeld, K., Selvaraj, P., Nunez, R. C., Hagedorn, B., George, L., Izzo, A., Palmer, A., Delport, D., Bennette, C., Wagner, B., Chang, S., Cohen, J. A., Panovska-Griffiths, J., Jastrzebski, M., ... Klein, D. J. (2020). Covasim: an agent-based model of COVID-19 dynamics and interventions. MedRxiv, 2020.05.10.20097469. https://doi.org/10.1101/2020.05.10.20097469

[44] Kimball, A., Hatfield, K. M., Arons, M., James, A., Taylor, J., Spicer, K., Bardossy, A. C., Oakley, L. P., Tanwar, S., Chisty, Z., Bell, J. M., Methner, M., Harney, J., Jacobs, J. R., Carlson, C. M., McLaughlin, H. P., Stone, N., Clark, S., Brostrom-Smith, C., ... Zane, S. (2020). Asymptomatic and Presymptomatic SARS-CoV-2 Infections in Residents of a Long-Term Care Skilled Nursing Facility — King County, Washington, March 2020. MMWR. Morbidity and Mortality Weekly Report, 69(13), 377-381. https://doi.org/10.15585/mmwr.mm6913e1

[45] Kumar, N., Shahul Hameed, S. K., Babu, G. R., Venkataswamy, M. M., Dinesh, P., Kumar, P. B., John, D. A., Desai, A., Ravi, V., \& Ravi Senior Professor, V. (2020). Epidemiology of SARS-CoV-2 infection in Karnataka State, South India: Transmission dynamics of symptomatic vs. asymptomatic infections. MedRxiv, 2020.09.17.20196501. https://doi.org/10.1101/2020.09.17.20196501

[46] Kumar, S., Gosain, M., Sharma, H., Swetts, E., Amarchand, R., Kumar, R., Lafond, K. E., Dawood, F. S., Jain, S., Widdowson, M.-A., Read, J. M., \& Krishnan, A. (2018). Who interacts with whom? Social mixing insights from a rural population in India. PLOS ONE, 13(12), e0209039. https://doi.org/10.1371/journal.pone.0209039

[47] Kumar, S., Gosain, M., Sharma, H., Swetts, E., Amarchand, R., Kumar, R., Lafond, K. E., Dawood, F. S., Jain, S., Widdowson, M. A., Read, J. M., \& Krishnan, A. (2018). Who interacts with whom? Social mixing insights from a rural population in India. PLOS ONE, 13(12), 1-17. https://doi.org/10.1371/journal.pone.0209039

[48] Lateef, F. (2010). Simulation-based learning: Just like the real thing. Journal of Emergencies, Trauma and Shock, 3(4), 348-352. https://doi.org/10.4103/0974-2700.70743

[49] Luke, D. A., \& Stamatakis, K. A. (2012). Systems science methods in public health: Dynamics, networks, and agents. Annual Review of Public Health, 33(April), 357-376. https://doi.org/10.1146/annurev-publhealth031210-101222

[50] Mahajan, A., Sivadas, N. A., \& Solanki, R. (2020). An epidemic model SIPHERD and its application for prediction of the spread of COVID-19 infection in India. Chaos, Solitons and Fractals, 140, 110156. 
https://doi.org/10.1016/j.chaos.2020.110156

[51] Mahdizadeh Gharakhanlou, N., \& Hooshangi, N. (2020). Spatio-temporal simulation of the novel coronavirus (COVID-19) outbreak using the agent-based modeling approach (case study: Urmia, Iran). Informatics in Medicine Unlocked, 20(August), 100403. https://doi.org/10.1016/j.imu.2020.100403

[52] Michael Barton, C., Alberti, M., Ames, D., Atkinson, J. A., Bales, J., Burke, E., Chen, M., Diallo, S. Y., Earn, D. J. D., Fath, B., Feng, Z., Gibbons, C., Hammond, R., Heffernan, J., Houser, H., Hovmand, P. S., Kopainsky, B., Mabry, P. L., Mair, C., ... Tucker, G. (2020). Call for transparency of COVID-19 models. In Science. https://doi.org/10.1126/SCIENCE.ABB8637

[53] Ministry of Health and Family Welfare (MoHFW). (2020). MoHFW. https://www.mohfw.gov.in/

[54] Models of Infectious Disease Agent Study (MIDAS): Online Portal for COVID-19 Modelling Research. (2020). Coordination Center University of Pittsburgh. https://midasnetwork.us/covid-19/

[55] Murray, M. (2002). Determinants of cluster distribution in the molecular epidemiology of tuberculosis. Proceedings of the National Academy of Sciences of the United States of America, 99(3), 1538-1543. https://doi.org/10.1073/pnas.022618299

[56] Noh, J. Y., Song, J. Y., Yoon, J. G., Seong, H., Cheong, H. J., \& Kim, W. J. (2020). Safe hospital preparedness in the era of COVID-19: The Swiss cheese model. In International Journal of Infectious Diseases (Vol. 98, Issue September, pp. 294-296). Elsevier B.V. https://doi.org/10.1016/j.ijid.2020.06.094

[57] Office of the Registrar General \& Census Commissioner. (2020). Ministry of Home Affairs, Government of India. https://censusindia.gov.in/

[58] Parasite Ecology. (2013). Density-dependent vs. Frequency-dependent Disease Transmission. https://parasiteecology.wordpress.com/2013/10/17/density-dependent-vs-frequency-dependent-diseasetransmission/

[59] Patrikar, S., Kotwal, A., Bhatti, V., Banerjee, A., Chatterjee, K., Kunte, R., \& Tambe, M. (2020). Incubation Period and Reproduction Number for novel coronavirus (COVID-19) infections in India. MedRxiv. https://doi.org/10.1101/2020.06.27.20141424

[60] Perez, L., \& Dragicevic, S. (2009). An agent-based approach for modeling dynamics of contagious disease spread. International Journal of Health Geographics, 8(1), 1-17. https://doi.org/10.1186/1476-072X-8-50

[61] Prem, K., Cook, A. R., \& Jit, M. (2017). Supporting information: Projected comtact matrices in 152 countries for models of contact-transmissible infectious diesases. PLoS Computational Biology, 110(46), 1-15. https://doi.org/10.1073/pnas.1314311110/-/DCSupplemental.www.pnas.org/cgi/doi/10.1073/pnas.1314311110

[62] RACGP - More evidence suggests no long-term COVID-19 immunity. (2020). https://www1.racgp.org.au/newsgp/clinical/more-evidence-suggests-no-long-term-covid-19-immun

[63] Roberts, M., Russell, L. B., Paltiel, A. D., Chambers, M., McEwan, P., \& Krahn, M. (2012). Conceptualizing a model: A report of the ISPOR-SMDM modeling good research practices task force-2. Value in Health, 15(6), 804-811. https://doi.org/10.1016/j.jval.2012.06.016

[64] Rockett, R. J., Arnott, A., Lam, C., Sadsad, R., Timms, V., Gray, K. A., Eden, J. S., Chang, S., Gall, M., Draper, J., Sim, E. M., Bachmann, N. L., Carter, I., Basile, K., Byun, R., O’Sullivan, M. V., Chen, S. C. A., Maddocks, S., Sorrell, T. C., ... Sintchenko, V. (2020). Revealing COVID-19 transmission in Australia by SARS-CoV-2 genome sequencing and agent-based modeling. Nature Medicine, 26(September). https://doi.org/10.1038/s41591-020-1000-7

[65] Rockwell Automation. (2017). Getting started with Arena. In Rockwell Automation. Supersedes Publication ARENA-UM001F-EN-P PN-111648. https://doi.org/10.2307/778906

[66] Samui, P., Mondal, J., \& Khajanchi, S. (2020). A mathematical model for COVID-19 transmission dynamics with a case study of India. Chaos, Solitons and Fractals, 140(November), 110173. https://doi.org/10.1016/j.chaos.2020.110173

[67] Sardar, T., Nadim, S. S., Rana, S., \& Chattopadhyay, J. (2020). Assessment of lockdown effect in some states and overall India: A predictive mathematical study on COVID-19 outbreak. Chaos, Solitons and Fractals, 139(October), 110078. https://doi.org/10.1016/j.chaos.2020.110078

[68] Shamil, M. S., Farheen, F., Ibtehaz, N., Khan, I. M., \& Rahman, M. S. (2020). An Agent Based Modeling of COVID-19: Validation, Analysis, and Recommendations. MedRxiv, 2020.07.05.20146977. https://doi.org/10.1101/2020.07.05.20146977

[69] Tako, A. A., \& Robinson, S. (2010). Comparing model development in discrete event simulation and system dynamics. Proceedings of the 2009 Winter Simulation Conference (WSC). https://doi.org/10.1109/WSC.2009.5429423

[70] Telangana State Portal State-Profile. (n.d.-br). Retrieved October 1, 2020, from https://www.telangana.gov.in/about/state-profile 
medRxiv preprint doi: https://doi.org/10.1101/2020.10.03.20206177; this version posted October 19, 2020. The copyright holder for this preprint

(which was not certified by peer review) is the author/funder, who has granted medRxiv a license to display the preprint in perpetuity.

It is made available under a CC-BY-NC-ND 4.0 International license .

[71] Tracy, M., Cerdá, M., \& Keyes, K. M. (2018). Agent-Based Modeling in Public Health: Current Applications and Future Directions. Annual Review of Public Health, 39(April), 77-94. https://doi.org/10.1146/annurevpublhealth-040617-014317

[72] Transmission of 2019-nCoV Infection from an Asymptomatic Contact in Germany | NEJM. (n.d.-bt). Retrieved August 26, 2020, from https://www.nejm.org/doi/full/10.1056/NEJMc2001468

[73] Tseng, K., Frost, I., Kapoor, G., Sriram, A., Nandi, A., \& Laxminarayan, R. (2020). Covid-19 India: Statelevel Estimates of Hospitalization Needs. CDDEP and Princeton University. https://cddep.org/wpcontent/uploads/2020/04/Covid.state_.hosp_3Apr2020.pdf

[74] Verma, V. R., Saini, A., Gandhi, S., Dash, U., \& Koya, S. F. (2020). Capacity-need gap in hospital resources for varying mitigation and containment strategies in India in the face of COVID-19 pandemic. Infectious Disease Modelling, 5(1), 608-621. https://doi.org/10.1016/j.idm.2020.08.011

[75] WHO Coronavirus disease 2019 (COVID-19) Situation Report - 46. (2020). https://www.who.int/docs/default-source/coronaviruse/situation-reports/20200306-sitrep-46-covid19.pdf?sfvrsn=96b04adf_4

[76] WHO Coronavirus disease 2019 (COVID-19) Situation Report - 73. (2020). https://apps.who.int/iris/bitstream/handle/10665/331686/nCoVsitrep02Apr2020eng.pdf?sequence $=1 \&$ isAllowed $=\mathrm{y}$

[77] Worldometer. (2020). Coronavirus Cases. Worldometer, 1-22. https://doi.org/10.1101/2020.01.23.20018549V2

[78] Zhang, Z., \& Jain, S. (2020). Mathematical model of Ebola and Covid-19 with fractional differential operators: Non-Markovian process and class for virus pathogen in the environment. Chaos, Solitons and Fractals, 140, 110175. https://doi.org/10.1016/j.chaos.2020.110175

[79] Zhao, W., Yu, S., Zha, X., Wang, N., Pang, Q., Li, T., \& Li, A. (2020). Clinical characteristics and durations of hospitalized patients with COVID-19 in Beijing: a retrospective cohort study. MedRxiv, April. https://doi.org/10.1101/2020.03.13.20035436 